\title{
The last glacial maximum and late glacial environmental and climate dynamics in the Baikal region inferred from an oxygen isotope record of lacustrine diatom silica
}

\author{
Svetlana S. Kostrova ${ }^{a}$, Hanno Meyer ${ }^{\text {b, *, }}$, Bernhard Chapligin ${ }^{b}$, Pavel E. Tarasov ${ }^{\text {, }}$ \\ Elena V. Bezrukova a \\ ${ }^{a}$ A.P. Vinogradov Institute of Geochemistry, Siberian Branch of Russian Academy of Sciences, Favorsky Str. 1a, 664033, Irkutsk, Russia \\ ${ }^{\mathrm{b}}$ Alfred Wegener Institute for Polar and Marine Research, Research Unit Potsdam, Telegrafenberg A43, 14473, Potsdam, Germany \\ ${ }^{c}$ Institute of Geological Sciences, Palaeontology, Free University Berlin, Malteserstr. 74-100, Building D, 12249, Berlin, Germany
}

\section{A R T I C L E I N F O}

Article history:

Available online $\mathrm{xxx}$

\section{Keywords:}

Lake sediments

Stable isotopes

Biogenic silica

Lake Kotokel

Palaeoclimate

Hydrological changes

\begin{abstract}
A B S T R A C T
The last glacial maximum and late glacial environmental and climatic variability in the Baikal region, southern Siberia, Russia has been studied in a sediment sequence from Lake Kotokel, located $2 \mathrm{~km}$ east of Lake Baikal, using the oxygen isotope composition of diatom silica $\left(\delta^{18} \mathrm{O}_{\text {diatom }}\right)$. The purification of diatom frustules involved the process of trimethylsilylation, which has been shown to be suitable for preparation of diatoms for oxygen isotope analysis. The Lake Kotokel $\delta^{18} \mathrm{O}_{\text {diatom }}$ record presented here spans intervals from about 24.6 to $22.9 \mathrm{ka}$ BP (further referred to as 'last glacial maximum') and $16.7-11.5 \mathrm{ka}$ BP (further referred to as 'late glacial') displaying variations in the oxygen isotope composition between +26.7 and $+31.2 \%$. Overall high $\delta^{18} \mathrm{O}_{\text {diatom }}$ values of about +29 to $+31 \%$ during the two investigated intervals characterize a strongly evaporative lake system in a dry environment and suggest a lower than present lake level due to enhanced evaporation. The Lake Kotokel diatom isotope record is roughly in line with the $60^{\circ} \mathrm{N}$ summer solar insolation, pointing to a linkage to broader-scale climate change, but displays weaker reaction to short-term climatic oscillations, i.e. Bølling-Allerød or Younger Dryas. The climate warming at $\sim 14.3 \mathrm{ka} B P$ is marked by negative spikes in the $\delta^{18} \mathrm{O}_{\text {diatom }}$ record due to isotopically low melt water input from the mountainous hinterland.
\end{abstract}

() 2014 Elsevier Ltd and INQUA. All rights reserved.

\section{Introduction}

Lacustrine sediments are unique carriers of information on past environmental conditions. They record the dynamics of biological productivity and physicochemical processes proceeding through entire lake life. Promising for studies are small shallow lakes, where a high velocity of sedimentation permits palaeoclimatic parameters to be recorded with annual to decadal resolution. A minimum of post-sedimentation changes in bottom sediments ensures accuracy of the acquired knowledge on past environmental and climate conditions at regional and global scale (Last and Smol, 2001; Peck et al., 2002; Subetto, 2009; Swann et al., 2010; Hernandez et al., 2013; Leng et al., 2013; Li et al., 2013). In the past decade

\footnotetext{
* Corresponding author.

E-mail addresses: kostrova@igc.irk.ru (S.S. Kostrova), hanno.meyer@awi.de, hmeyer@awi-potsdam.de (H. Meyer), bernhard.chapligin@awi.de (B. Chapligin), ptarasov@zedat.fu-berlin.de (P.E. Tarasov), bezrukova@igc.irk.ru (E.V. Bezrukova).

researchers have paid special attention to investigating past climate changes and factors leading to switches between glacial and interglacial conditions. Numerous studies have shown the transition from cold and dry glacial to warm and wet interglacial climate led to major environmental alterations in the terrestrial part of lake catchments and in aquatic ecosystems (Morley et al., 2005; Stebich et al., 2009; Müller et al., 2010; Hernandez et al., 2011; Cook et al., 2012; Zhao et al., 2013).

The millennial- to century-scale climatic events, such as the last glacial maximum (LGM), the Meiendorf (MD), Bølling (BO) and Allerød (AL) warming phases, the Oldest Dryas (OstD), Older Dryas (OD) and Younger Dryas (YD) cold events were exposed by highresolution and accurately dated proxy records from terrestrial archives (Wang et al., 2001; Yuan et al., 2004; Svensson et al., 2008) and lake sediments (Litt and Stebich, 1999; Yu and Eicher, 2001; Nakagawa et al., 2005; Diefendorf et al., 2006; Stebich et al., 2009; Zhao et al., 2013), providing important information about the rate, amplitude and driving mechanisms of these climatic events. 
The Lake Baikal region in the extremely continental part of Eurasia (Fig. 1a) located far from oceanic influences is one of the world's most sensitive regions to abrupt climate shifts and multimillennial variability (Prokopenko et al., 2001; Mackay, 2007; Tarasov et al., 2007; Kuzmin et al., 2009; Sklyarov et al., 2010; Shichi et al., 2013). To date, the last and late glacial climate and environment development history in the region was primarily reconstructed based on multi-proxy data from Lake Baikal (Prokopenko et al., 2001; Karabanov et al., 2004; Boës et al., 2005; Demske et al., 2005; Morley et al., 2005; Mackay, 2007; Kuzmin et al., 2009; Mackay et al., 2011) and using pollen and diatom records from the relatively small (about $69 \mathrm{~km}^{2}$ ) and shallow (about $4 \mathrm{~m}$ mean water depth) Lake Kotokel (Zhang et al., 2013) located near Lake Baikal (Fig. 1) (e.g. Bezrukova et al., 2008, 2010, 2011;
Shichi et al., 2009; Tarasov et al., 2009; Müller et al., 2013). The obtained high-resolution sedimentary records from Lake Kotokel (Müller et al., 2013) revealed the cold and dry LGM (between 26.5 and $19 \mathrm{ka} \mathrm{BP}$; here and throughout the entire article calendar ages are consistently used) with highest scores for steppe biome, minor woody coverage, very low diatom concentrations and low lake level. A slight climate amelioration is reconstructed at 24-22 ka BP. A gradual increase in tree/shrub pollen percentages and increase in diatoms is noticeable at $17.0-11.65 \mathrm{ka}$ BP (Bezrukova et al., 2010). The deepening of the lake and increase in the woody coverage to $20-30 \%$ at $\sim 14.5-14.0$ and $\sim 13.3-12.8 \mathrm{ka}$ BP gave clear evidence for the MD and AL interstadials. The YD cooling in the Baikal region at $12.7-11.65 \mathrm{ka} B \mathrm{~B}$ is well recognizable in the Lake Kotokel records by an increase in tundra biome scores and

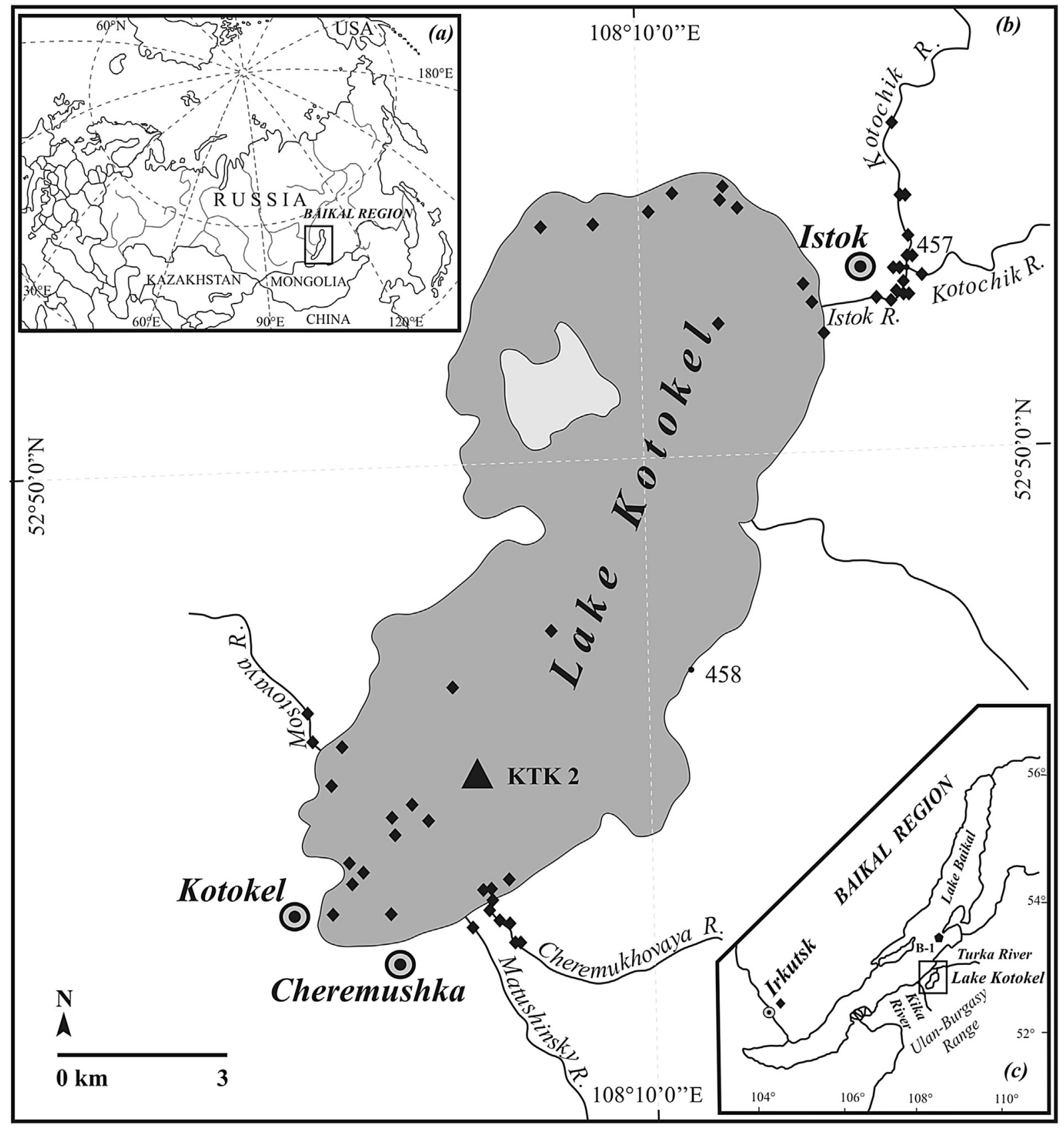

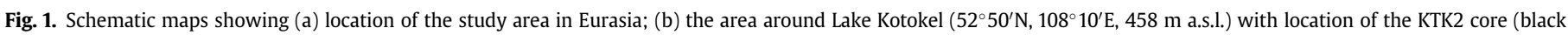
triangle) and water sampling sites (black rhombus) used in this study; and (c) the Baikal region with recent diatom sampling site position (black pentagon). 
pronounced changes in the diatom species composition (Bezrukova et al., 2010) and in Lake Baikal through variations in diatom abundance and diatom $\delta^{18} \mathrm{O}$ values, organic matter and $\delta^{13} \mathrm{C}$ values as well as by a lowering of grey scale values (Prokopenko and Williams, 2004; Boës et al., 2005; Kuzmin et al., 2009; Mackay et al., 2011). The variations in each proxy through the last glaciation are considered to be due to variability in biological activity and sedimentation rates.

A number of qualitative climatic and environment reconstructions published to date demonstrate a complicated and partly controversial picture of climate changes during the LGM and late glacial in the Baikal region (Boës et al., 2005; Demske et al., 2005; Bezrukova et al., 2010; Mackay et al., 2011). Therefore, oxygen isotope data from small lakes in the region could be helpful in resolving some of the problematic questions, as recently demonstrated by the Holocene oxygen isotope record of diatoms from Lake Kotokel (Kostrova et al., 2013a, b).

Because the oxygen isotope analysis of diatom silica requires highly pure samples, various chemical and physical procedures need to be applied to separate diatom frustules from sediment material (Morley et al., 2004; Leng and Barker, 2006; Swann and Leng, 2009; Chapligin et al., 2012; and references therein). The use of different purification approaches is often unavoidable and dictated by the availability of certain chemicals and laboratory equipment. Hydrogen peroxide $\left(\mathrm{H}_{2} \mathrm{O}_{2}\right)$ and various acids $\left(\mathrm{HNO}_{3}, \mathrm{HClO}_{4}, \mathrm{HCl}\right)$ are generally used for organic and carbonate removal. Clay, silts and other remaining contaminants are then separated by sieving at a size fraction, which needs to be adjusted according to the size of diatom frustules and contaminants in the sediment assemblage. Heavy liquid separation (HLS) with sodium polytungstate (SPT; $3 \mathrm{Na}_{2} \mathrm{WO}_{4} \cdot 9 \mathrm{WO}_{3} \cdot \mathrm{H}_{2} \mathrm{O}$ ) is also used (Morley et al., 2004; Chapligin et al., 2012). Within this study the clean-up procedure involved the process of trimethylsilylation (Laufer and Roy, 1972; Kashutina et al., 1975; Iler, 1979). Even though the approach was employed earlier by Kalmychkov et al. (2005, 2007) and Kostrova et al. (2013a, b), the question whether the trimethylsilylation reaction (TMSR) by using trimethylchlorosilane (TMCS; $\left.\left(\mathrm{CH}_{3}\right)_{3} \mathrm{SiCl}\right)$ influences the final oxygen isotope composition of diatoms is still under debate and is therefore additionally investigated within this study. This information is needed to assess whether diatom oxygen isotopes prepared with this technique are reliable proxies for palaeoclimate reconstruction. We furthermore aim to present the recently obtained oxygen isotope record of diatoms extracted from Lake Kotokel sediments accumulated $\sim 24.6-22.9 \mathrm{ka}$ BP and $16.7-11.5 \mathrm{ka}$ BP. Together with the existing reconstruction derived from pollen and diatom records from the same sediment core and the other published data, our new record is then used to discuss the environmental dynamics and climate history of the region for the last glacial maximum and the late glacial.

\section{Regional setting}

\subsection{Site location, morphology and hydrology of the lake}

Lake Kotokel (458 m a.s.l.; Fig. 1), situated between the Kika and Turka rivers in south-eastern Siberia, is $15 \mathrm{~km}$ long and about $6 \mathrm{~km}$ wide with a catchment area of approximately $187 \mathrm{~km}^{2}$ (Zhang et al., 2013) and a relatively short water residence time of about 7 years (Shichi et al., 2009). The lake basin $\left(52^{\circ} 45^{\prime}-52^{\circ} 52^{\prime} \mathrm{N}\right.$; $108^{\circ} 04^{\prime}-108^{\circ} 12^{\prime}$ E) of Cenozoic age (Florensov, 1960) is separated from Lake Baikal by a low-elevation mountain ridge (up to $729 \mathrm{~m}$ a.s.l.). Both the southern and northern parts of the lake are similar in basin morphology, comprising an almost flat lake bottom (Zhang et al., 2013). The lake has an outflow to Lake Baikal via the Istok-Kotochik-Turka river-system and depending on the precipitation amount in the Kotokel-Kotochik catchments, the River Istok might seasonally flow into Lake Kotokel (Kuz'mich, 1988; Kostrova et al., 2013a). However, there is no evidence that the Lake Baikal water (and diatoms) has penetrated to Lake Kotokel during the last $50 \mathrm{ka}$ (Shichi et al., 2009; Bezrukova et al., 2010; Zhang et al., 2013). The lake is well-mixed, the average water temperature from May to October is about $18{ }^{\circ} \mathrm{C}$ and it is generally ice-covered from November to early May (Kostrova et al., 2013a and references therein).

\subsection{Modern climate}

The Baikal region, including the study area, is characterized by a continental climate with long, cold and relatively dry winters and short, moderately warm and wet summers. Mean daily air temperatures around Lake Kotokel in July are $+15.4{ }^{\circ} \mathrm{C}$, falling to about $-19.5^{\circ} \mathrm{C}$ in January (Galaziy, 1993). Westerly winds prevail in the region throughout the year (Lydolph, 1977). Annual precipitation sums reach approximately $400 \mathrm{~mm}$ (Galaziy, 1993). Almost a half of it falls in July and August during increasing south-eastern cyclonic activity along the Mongolian branch of the Polar front, whereas between late autumn and early spring, when cold and sunny weather associated with the Siberian High centred over eastern Siberia and Mongolia predominates, precipitation is generally low (Lydolph, 1977; Kurita et al., 2004; Bezrukova et al., 2008; Tarasov et al., 2009).

\section{Material and methods}

\subsection{Sampling, core lithology and age determination}

In August 2005 a $12.53 \mathrm{~m}$ long sediment core (KTK2; 52 ${ }^{\circ} 47^{\prime} \mathrm{N}$, $108^{\circ} 07^{\prime} \mathrm{E}$; water depth of about $3.5 \mathrm{~m}$ ) was retrieved using a Livingston-type piston corer from the southern part of Lake Kotokel (Fig. 1b) and subsequently studied for lithology, pollen and diatoms (Shichi et al., 2009; Bezrukova et al., 2010). In this study, a $530 \mathrm{~cm}$-long section of Lake Kotokel sediments $(1030-500 \mathrm{~cm}$ of the core depth) was chosen for diatom oxygen isotope investigation. A recent lithological study on the KTK2 core (Bezrukova et al., 2010) reported that the selected part of the KTK2 core (Fig. 2a) consists of grey to dark-grey silty clay $(1030-1010 \mathrm{~cm})$, laminated grey silty clay $(1010-740 \mathrm{~cm})$, grey-blackish slightly laminated silty clay $(740-660 \mathrm{~cm})$ and soft brownish-black gyttja $(660-500 \mathrm{~cm})$ deposited between $\sim 31.9$ and $\sim 11.5 \mathrm{ka}$ BP. The details of the KTK2 core chronology was established on the basis of eleven calibrated AMS radiocarbon dates and the age-depth model for the studied section are presented in Bezrukova et al., 2010 and in Fig. 2a.

For the investigation of the TMSR purification as an alternative to HLS, a sample was used where fossil diatoms were separated from the terrigenous fraction of Lake Baikal sediments (sample "PL"). A second sample used for this test (sample "B1") comprised recent diatoms collected in the central basin of Lake Baikal $\left(53^{\circ} 18^{\prime} \mathrm{N}, 108^{\circ} 23^{\prime} \mathrm{E}\right.$; see Fig. 1c for sampling locations) with net-trap equipment in June 2013. Both samples were dominated by Aulacoseira baicalensis species (up to 98.5\%). Additionally, the PL-sample contained Aulacoseira islandica and Aulacoseira subarctica, whereas the B1-sample contained Cyclotella baicalensis and Synedra acus. To test the effect of TMSR on diatoms both samples were divided in two equal parts and exposed to SPT and TMCS. The oxygen isotope composition was measured before and after the respective purification steps were taken.

\subsection{Diatom record}

The diatom record from the KTK2 core of Lake Kotokel presented by Bezrukova et al. (2010) reveals a total of 143 diatom taxa through 


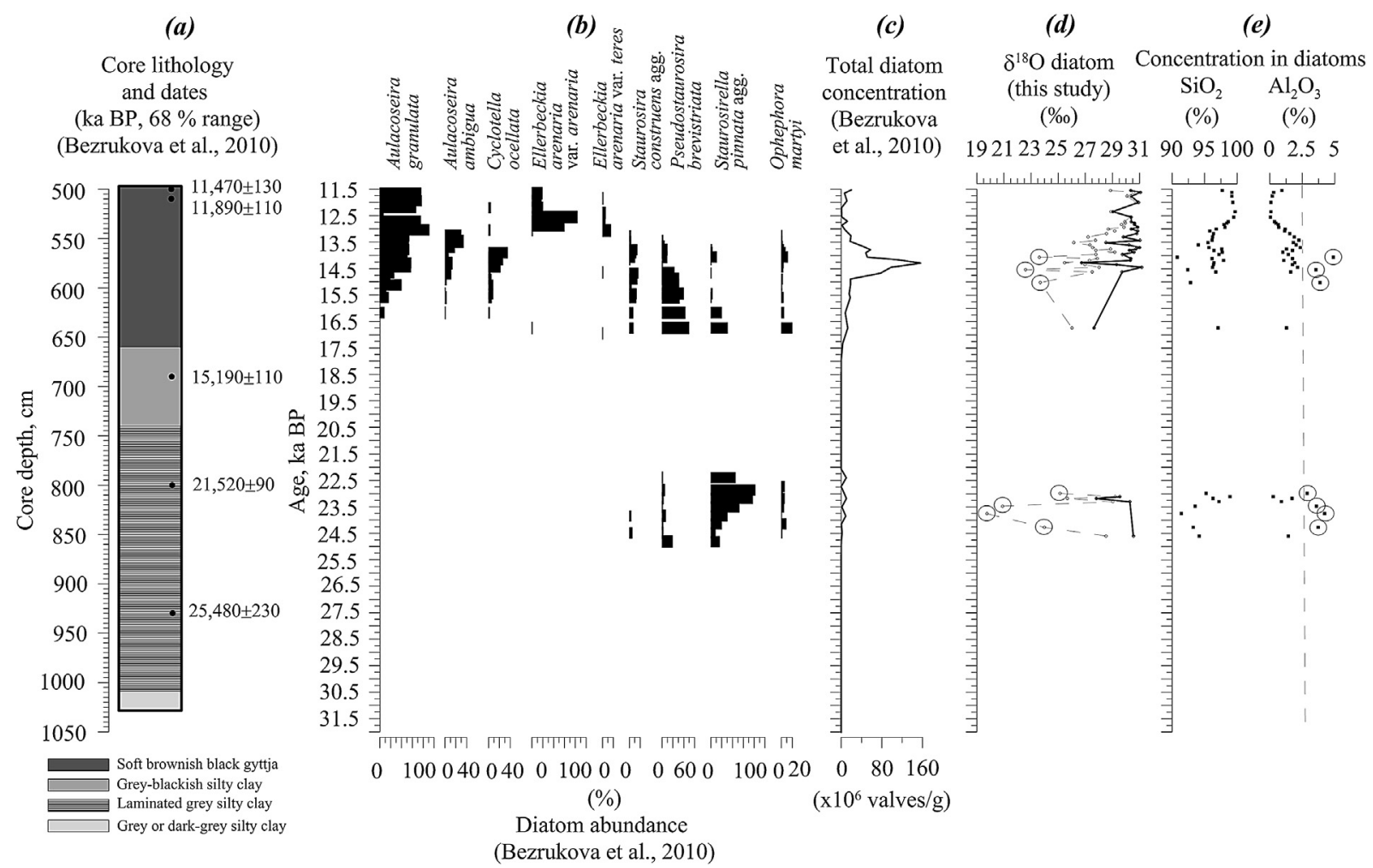

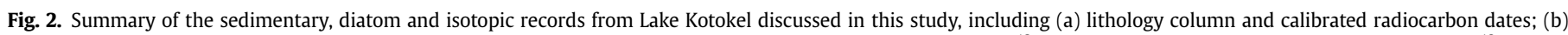

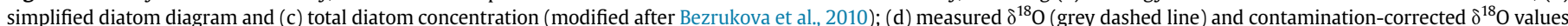

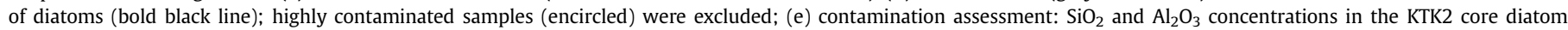
samples analyzed by EDS.

the whole sediment sequence accumulated since about $47 \mathrm{ka}$ BP. The diatom record for the part of the core selected for this study is presented in Fig. 2b. The intervals from $\sim 31.9$ to $\sim 24.7 \mathrm{ka}$ BP $(1030-895 \mathrm{~cm})$ and from $\sim 22.0$ to $\sim 17.0 \mathrm{ka} \mathrm{BP}(820-720 \mathrm{~cm})$ reveal extremely low diatom concentrations (Fig. 2c) and have been excluded from further analysis. The interval $\sim 24.7-21.9 \mathrm{ka}$ BP is dominated by the small benthic Staurosirella pinnata agg. complex (up to $82 \%$; Fig. 2b). However, the total diatom concentration remains low, i.e. between 0.3 and $10.3 \times 10^{6}$ valves $g^{-1}$ (Fig. $2 \mathrm{c}$ ). A progressive increase in the abundance of planktonic Aulacoseira granulata (up to 91\%), Aulacoseira ambigua (up to 34\%), Cyclotella ocellata (up to 35\%) diatoms is accompanied by a pronounced decrease in benthic species Pseudostaurosira brevistriata, S. pinnata agg. and Ophephora martyi in the interval between 720 and $543 \mathrm{~cm}$ KTK2 core depth dated to $17.0-12.7 \mathrm{ka}$ BP (Fig. 2a and $\mathrm{b})$. The total diatom concentration reaches its maximum of $156.3 \times 10^{6}$ valves $\mathrm{g}^{-1}$ at $\sim 14.3 \mathrm{ka} \mathrm{BP}$ and decreases to $19.1 \times 10^{6}$ valves $\mathrm{g}^{-1}$ towards $\sim 12.7 \mathrm{ka} \mathrm{BP}$ (Fig. $2 \mathrm{c}$ ). The diatom assemblages between $\sim 12.7$ and $11.5 \mathrm{ka}$ BP $(543-500 \mathrm{~cm})$ are dominated by $A$. granulata (up to $77 \%$ ), Ellerbeckia arenaria var. arenaria (up to $84 \%$ ) and E. arenaria var. teres (up to $15 \%$; Fig. 2 b).

\subsection{Water sampling and stable water isotope analysis}

Surface water from Lake Kotokel and water from the rivers connected to the lake were sampled during May and July 2011, in March, September and November 2012 as well as in July and August 2013. The water sampling site locations are presented in Fig. $1 \mathrm{~b}$. Atmospheric precipitation samples were collected during the time period from June 2011 to October 2013 in Irkutsk, about $270 \mathrm{~km}$ west of Lake Kotokel. After sampling, all specimens were stored cool in airtight bottles prior to isotope analyses. A total of 178 water samples were analyzed for hydrogen and oxygen isotopes with a Finnigan MAT Delta-S mass spectrometer at the Isotope Laboratory of the Alfred Wegener Institute for Polar and Marine Research (AWI Potsdam, Germany) using equilibration techniques. Stable isotope data $\left(\delta^{18} \mathrm{O}, \delta \mathrm{D}\right.$ and $d$ excess), including minimum, mean and maximum values, standard deviations (SD) for the analyzed samples, as well as water and air temperatures are summarized in Table 1. Data are given as per mil difference to V-SMOW, with internal $1 \sigma$ errors of better than $\pm 0.8 \%$ and $\pm 0.1 \%$ for $\delta \mathrm{D}$ and $\delta^{18} \mathrm{O}$, respectively (Meyer et al., 2000).

\subsection{Sampling preparation and purity estimation}

In total, 63 samples with a 4-cm step (an average temporal resolution of about 110 years) from diatoms-containing intervals of the KTK2 core dated to the LGM and late glacial (Bezrukova et al., 2010) were prepared for diatom oxygen isotope analysis following a separation and cleaning method first applied by Kalmychkov et al. (2005) at the Vinogradov Institute of Geochemistry SB RAS (VIG SB RAS, Irkutsk) and described in Kostrova et al. (2013a). This procedure includes $\mathrm{H}_{2} \mathrm{O}_{2}$ and nitric/perchloric acids $\left(\mathrm{HNO}_{3}: \mathrm{HClO}_{4}\right)$ mixture treatment and sieving with $5 \mu \mathrm{m}$ mesh size to remove organic matter and clay particles, respectively, as well as a modification of diatom surfaces using TMSR (Laufer and Roy, 1972; Kashutina et al., 1975; Iler, 1979):

$$
\equiv \mathrm{Si}-\mathrm{OH}+\left(\mathrm{CH}_{3}\right)_{3} \mathrm{Si}-\mathrm{Cl} \rightarrow \equiv \mathrm{Si}-\mathrm{O}-\mathrm{Si}\left(\mathrm{CH}_{3}\right)_{3}+\mathrm{HCl}_{(\text {gas }) \uparrow}
$$

TMSR is conducted in a non-polar environment, i.e. $n$-hexane $\left(\mathrm{C}_{6} \mathrm{H}_{14}\right)$ or chloroform $\left(\mathrm{CHCl}_{3}\right)$ in order to avoid any additional 


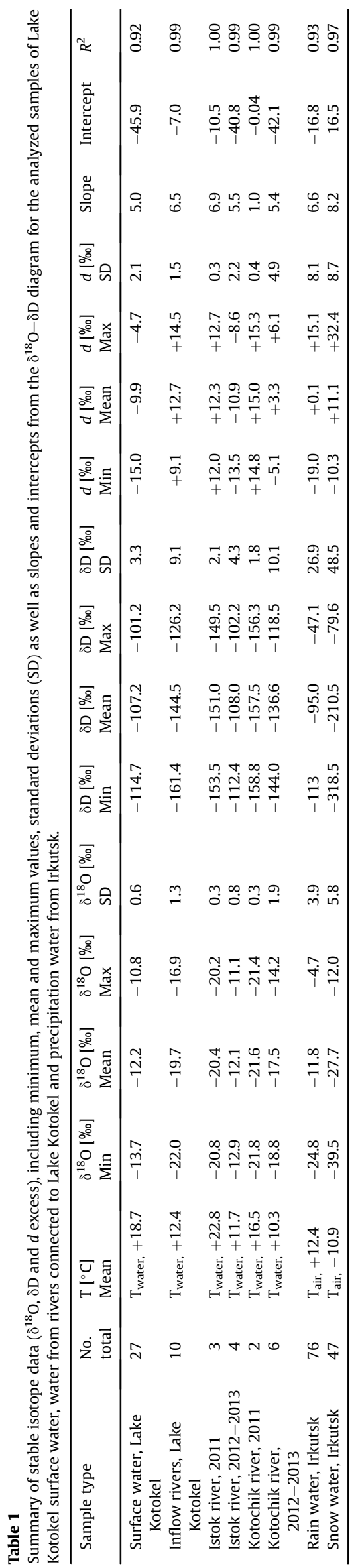

oxygen and facilitate the removal of by-products (Kalmychkov et al., 2005). During this process protons of surface silanol groups $(\equiv \mathrm{Si}-\mathrm{OH})$ are substituted by non-polar radicals, resulting in diatoms becoming hydrophobic. Hence, the process causes diatom material to float on top of a water column, while all other components sink. Depending on the degree of sample purity an additional HLS was performed.

The purity of the obtained diatom preparations was estimated by the method of Chapligin et al. (2012) using Scanning Electron Microscopy (SEM) and Energy-Dispersive X-ray Spectroscopy (EDS) with a ZEISS ULTRA 55 Plus Schottky-type field emission scanning electron microscope equipped with an energy-dispersive system and a silicon drift detector (UltraDry SDD; Thermo Fisher Scientific) at the German Research Centre for Geoscience (GFZ), Potsdam. The quantitative analysis was performed using the standardless procedure (3-5 repetitions, an acceleration voltage of $20 \mathrm{kV}$; excitedarea size of $200-250 \mu \mathrm{m}$, measuring time of $2 \mathrm{~min}$ ); the results were expressed as weight percentages and displayed as oxides.

According to the EDS data (Fig. 2e), out of the 63 prepared diatom samples, 9 ranged between 97.2 and $99.6 \% \mathrm{SiO}_{2}$, and between 0.1 (detection limit) and $0.7 \% \mathrm{Al}_{2} \mathrm{O}_{3}$; and 5 contained 95-97\% $\mathrm{SiO}_{2}$, and about $1.5 \% \mathrm{Al}_{2} \mathrm{O}_{3}$. These 14 specimens were analyzed for oxygen isotopes without additional cleaning. Among the remaining 49 samples, 10 samples, mainly those extracted from the core interval dated to $\sim 25.0-22.0 \mathrm{ka} \mathrm{BP}$, were not suitable for isotopic analysis due to small residual masses and high contamination $\left(<90 \% \mathrm{SiO}_{2}\right.$ and up to $12 \% \mathrm{Al}_{2} \mathrm{O}_{3}$ ). 22 other samples small in weight and containing $85-94 \% \mathrm{SiO}_{2}$ and up to $3-5 \% \mathrm{Al}_{2} \mathrm{O}_{3}$ were combined into seven samples, and then subjected to an additional HLScleaning together with the remaining 17 samples (91-95\% $\mathrm{SiO}_{2}$ and $1.9-4.3 \% \mathrm{Al}_{2} \mathrm{O}_{3}$ ). After the HLS-cleaning procedure the $\mathrm{Al}_{2} \mathrm{O}_{3}$ content decreased to $1.3-4.0 \%$ and the $\mathrm{SiO}_{2}$ content increased up to 90-97\%. SPT-cleaning only partly allowed a satisfactory separation between the terrigenous and diatom fractions. Finally, 38 samples were further processed and analyzed for their oxygen isotope composition.

\subsection{Oxygen isotope analysis}

The oxygen isotope composition of clean diatom material was measured using the method published in Chapligin et al. (2010) with a PDZ Europa 2020 mass spectrometer (MS-2020; now supplied by Sercon Ltd., UK) at the AWI in Potsdam. Prior to isotope analysis, the samples were heated up to $1100^{\circ} \mathrm{C}$ and cooled down to $400{ }^{\circ} \mathrm{C}$ in approximately $7 \mathrm{~h}$ under a flow of He gas (inert Gas Flow Dehydration (iGFD)) to remove any exchangeable groups in the amorphous biogenic structure containing oxygen (Chapligin et al., 2010). The dehydrated samples (about $2 \mathrm{mg}$ ) were then fully reacted by laser fluorination under $\mathrm{BrF}_{5}$ atmosphere to liberate $\mathrm{O}_{2}$ (Clayton and Mayeda, 1963), which was then separated from byproducts and directly measured against an oxygen reference sample of known isotopic composition. The working standard BFC (Chapligin et al., 2011) was used (this study: $\delta^{18} \mathrm{O}=+28.8 \pm 0.27 \%$; $n=15$; inter-laboratory comparison: $+29.0 \pm 0.3 \%$ ). The oxygen isotope composition of diatom silica is expressed on the delta scale in per mil (\%o). The final $\delta^{18} \mathrm{O}$ value of the diatom sample is calculated relative to $\mathrm{V}$-SMOW standard with a long-term analytical reproducibility of $\pm 0.25 \%$ (Chapligin et al., 2010).

\subsection{Contamination assessment and correction of isotope measurements}

Due to potential changes in $\delta^{18} \mathrm{O}$ values caused by any contamination left in purified samples, the measured $\delta^{18} \mathrm{O}$ signals 
were corrected using a geochemical mass-balance approach (Brewer et al., 2008; Swann and Leng, 2009; Chapligin et al., 2012):

$\delta^{18} \mathrm{O}_{\text {corrected }}=\left(\delta^{18} \mathrm{O}_{\text {measured }}-\delta^{18} \mathrm{O}_{\text {contamination }} \cdot \mathrm{c}_{\text {contamination }} / 100\right) /$ $\left(c_{\text {diatom }} / 100\right)$,

where $\delta^{18} \mathrm{O}_{\text {measured }}$ is the original measured value $\delta^{18} \mathrm{O}$ of the analyzed sample, $\delta^{18} \mathrm{O}_{\text {corrected }}$ is the measured $\delta^{18} \mathrm{O}$ value corrected for contamination, $\delta^{18} \mathrm{O}_{\text {contamination }}=+10.5 \%$ and represents the average $\delta^{18} \mathrm{O}$ value of the analyzed terrigenous samples (heavy fractions from all core samples merged into three samples $(540-720 \mathrm{~cm}, 695-830 \mathrm{~cm}, 840-895 \mathrm{~cm})$ to gain enough material for both EDS and isotope analyses) and $\mathrm{c}_{\text {contamination }}$ and $\mathrm{c}_{\text {diatom }}$ are the percentages of contamination and diatom material respectively within the analyzed sample. The percentage of contamination is calculated by the EDS measured $\mathrm{Al}_{2} \mathrm{O}_{3}$ content of the individual sample divided by the average $\mathrm{Al}_{2} \mathrm{O}_{3}$ content of the contamination ( $14.2 \%$ in heavy fractions). The percentage of diatom material is calculated as $\left(100 \%-\mathrm{c}_{\text {contamination }}\right)$.

Seven samples with more than $2.5 \% \mathrm{Al}_{2} \mathrm{O}_{3}$ according to EDS analysis (Fig. 2e) were discarded from further interpretation because above this limit the geochemical mass-balance correction technique could cause excessive shifts in $\delta^{18} \mathrm{O}$ values (Chapligin et al., 2012).

\section{Results}

\subsection{Water isotope analysis}

Water isotope data for the Baikal region includes the results of stable isotope analysis of water samples collected in summer 2011 published by Kostrova et al. (2013a) and new data collected during the monitoring period between 2011 and 2013. All results of isotope analyses are summarized in Table 1 and presented in a $\delta^{18} \mathrm{O}-\delta \mathrm{D}$ diagram (Fig. 3) with respect to the Global Meteoric Water Line (GMWL; $\delta \mathrm{D}=8 \cdot \delta^{18} \mathrm{O}+10$ ), in which fresh surface waters (Craig,

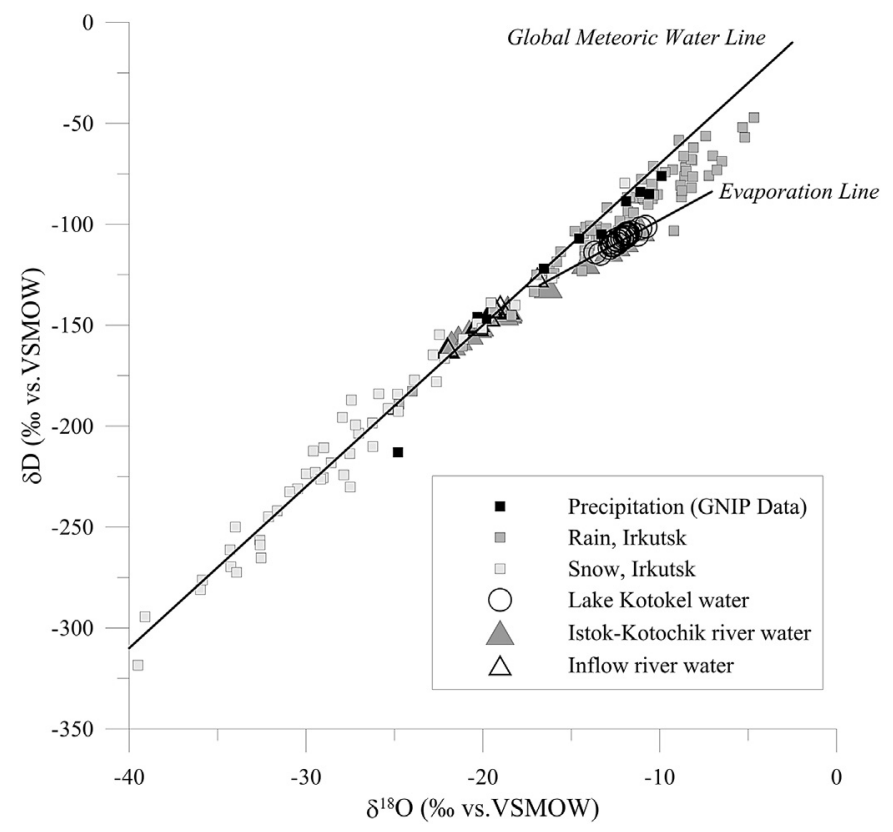

Fig. 3. $\delta^{18} \mathrm{O}-\delta \mathrm{D}$ diagram for Lake Kotokel and rivers connected to the lake as well as rain and snow water (sampled in Irkutsk) collected between 2011 and 2013 (compare Table 1). Additionally, GNIP data for Irkutsk precipitation, the Global Meteoric Water Line as well as an evaporation line for Lake Kotokel water are given.
1961) and precipitation (Rozanski et al., 1993) are correlated on a global scale. The recent stable isotope composition of the surface Lake Kotokel water during sampling periods varied between $-10.8 \%$ and $-13.7 \%$ for $\delta^{18} \mathrm{O}$ and from $-101.2 \%$ to $-114.7 \%$ for $\delta \mathrm{D}$. The $d$ excess changes from $-4.7 \%$ to $-14.8 \%$ o with a mean value of $-9.1 \%$. All rivers draining into Lake Kotokel show a mean isotopic composition of around $-19.7 \%$ in $\delta^{18} \mathrm{O}$, and $-144.5 \%$ in $\delta \mathrm{D}$ (mean $d$ excess around $+12.7 \%$ ). Baikal region rain samples are characterized by mean values of $-11.8 \%$ for $\delta^{18} \mathrm{O}$, and $-95.0 \%$ for $\delta \mathrm{D}$ (the $d$ excess is $+0.1 \%$ ) whereas snow samples display mean $\delta^{18} \mathrm{O}, \delta \mathrm{D}$ and $d$ excess values of $-27.7 \%$, $-210.5 \%$ and $+11.1 \%$, respectively.

\subsection{Influence of TMSR on the oxygen isotope composition}

Fossil (PL) and recent (B1) diatom samples were initially analyzed by EDS. The PL-sample contained $98.8 \pm 0.4 \%(n=7) \mathrm{SiO}_{2}$, and $0.1 \pm 0.1 \%(n=7) \mathrm{Al}_{2} \mathrm{O}_{3}$. Concentrations of $\mathrm{SiO}_{2}$ and $\mathrm{Al}_{2} \mathrm{O}_{3}$ were $99.4 \pm 0.3 \%(n=7)$, and $0.01 \pm 0.03 \%(n=7)$, respectively in the $\mathrm{B} 1-$ sample. Both samples were successively processed by using SPT for HLS (Morley et al., 2004; Chapligin et al., 2012) and TMCS for TMSR (Kalmychkov et al., 2005). The oxygen isotope composition for the PL-sample was $+22.2 \%$ before the questioned purification measures were taken and $+22.4 \%$ versus $+22.0 \%$ after SPT- and TMCS-treatments, respectively. The $\delta^{18} \mathrm{O}$ values for the B1-sample were $+21.5 \%$ before and $+21.9 \%$ after HLS and $+21.5 \%$ after TMSR.

\subsection{Diatom oxygen isotope analysis}

The $\delta^{18} \mathrm{O}_{\text {corrected }}$ values from the investigated segments (842-892 and 500-715 cm depth) within the KTK2 core vary between +26.7 and $+31.2 \%$ (Fig. $2 \mathrm{~d}$ ). In general, the $\delta^{18} \mathrm{O}_{\text {corrected }}$ values for the diatom samples follow the same trend as the

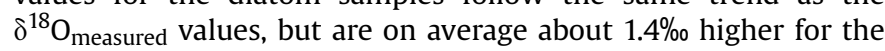
part of the core spanning the time period from $\sim 24.6$ to $22.9 \mathrm{ka} \mathrm{BP}$ (7.4\% average contamination) and approximately $2.0 \%$ higher for the interval between $\sim 16.7$ and 12.7 ka BP (10.2\% average contamination). In the following, we use the corrected data of diatom samples containing less than $2.5 \% \mathrm{Al}_{2} \mathrm{O}_{3}$ (or $>15 \%$ contamination) for interpretation.

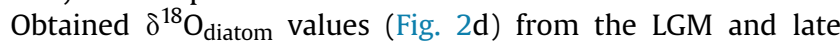
glacial intervals generally match the range of other lacustrine diatom records $(+15$ to $+40 \%$ ) (Leng and Barker, 2006 and references therein; Swann et al., 2010; Mackay et al., 2011; Hernandez et al., 2013) as well as that from Holocene Lake Kotokel diatoms (Kostrova et al., 2013a, b). The interval between 24.6 and $23.0 \mathrm{ka}$ BP displays relatively constant $\delta^{18} \mathrm{O}_{\text {diatom }}$ values about of $+30.1 \%$ with a visible spike of $+27.8 \%$ at $\sim 23.2 \mathrm{ka}$ BP. The

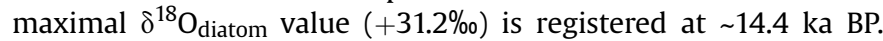
After a sharp drop to $+26.7 \%$ at $\sim 14.2 \mathrm{ka}$ BP - the absolute minimum in the $\delta^{18} \mathrm{O}$ record - and a subsequent rise to $+30.3 \%$, the $\delta^{18} \mathrm{O}$ values gradually increase to $+31.0 \%$ from $\sim 14.1$ to $13.7 \mathrm{ka} \mathrm{BP}$. A decline of $2.5 \%$ in the KTK2 isotope record is observed at 13.7-13.5 ka BP. After rapid increase to $+31.0 \%$ at $13.4 \mathrm{ka} \mathrm{BP} \mathrm{a}$ smaller minimum with a $\delta^{18} \mathrm{O}$ value of $+29.8 \%$ occurs at $\sim 13.3 \mathrm{ka}$ BP. The interval $\sim 13.2-12.5 \mathrm{ka}$ BP is characterized by relatively stable $\delta^{18} \mathrm{O}$ values ranging between +30.4 and $+30.9 \%$. At $\sim 12.3 \mathrm{ka}$ BP there is another minimum in $\delta^{18} \mathrm{O}$ with $+29.0 \%$. After $\sim 12.3 \mathrm{ka} \mathrm{BP}, \delta^{18} \mathrm{O}$ values increase to $+31.1 \%$ in the upper part of the core. In general, a gradual enrichment of $\sim 3.5 \%$ in $\delta^{18} \mathrm{O}$ is observed in diatom frustules during the period $\sim 17.0-11.5 \mathrm{ka}$ BP (Fig. 2d). Here, the linear correlation between $\delta^{18} \mathrm{O}_{\text {diatom }}$ and calibrated ages (in yr) yields: $\delta^{18} \mathrm{O}_{\text {diatom }}=-0.0005 \mathrm{yr}+36.37 \%$ $\left(R^{2}=0.23\right)$. 


\section{Discussion}

\subsection{The effect of TMSR on the oxygen isotope signal}

A variety of techniques have been developed for the extraction and cleaning of diatoms (see Chapligin et al., 2012 for more details) for stable isotope analysis. The purification procedure used in this study involves a complex cleaning protocol which was first reported by Kalmychkov et al. $(2005,2007)$ and recently applied by Kostrova et al. (2013a, b).

Any chemical reaction including the applied acid exposure or TMSR may probably cause a change on the frustules' surface as rupture of siloxane ( $\equiv \mathrm{Si}-\mathrm{O}-\mathrm{Si} \equiv$ ) bonds and therefore does not guarantee a good preservation of the oxygen-isotope signal during preparation of a sample for isotope analysis. Brandriss et al. (1998) noted the effect of hot acids on fresh diatoms causing the increase of $\delta^{18} \mathrm{O}$ values of 1.8 and $5.3 \%$, whereas the same treatment had no effect on fossil diatoms.

The PL-sample shows a $\pm 0.2 \%$ difference in $\delta^{18} \mathrm{O}$ values before and after SPT- and TMCS-treatment was undertaken. For sample B1 no difference in the oxygen isotope composition was observed before and after TMSR, whereas after carrying out HLS a slight difference of $+0.4 \%$ was found. For both samples the difference between $\delta^{18} \mathrm{O}$ value before and after SPT- and TMCS-processing was within the instrument's margin of error ( $S D= \pm 0.25 \%$ ). Hence, these changes are not significant and do not relate to potential structural changes in diatoms. Thus, TMSR does not provoke a modification of the oxygen isotope composition and can be applied for the extraction and cleaning of diatom from terrigenous matter as an alternative to HLS.

\subsection{Potential controls for the diatom isotope record}

Variations in $\delta^{18} \mathrm{O}_{\text {diatom }}$ values of lacustrine sediment are mainly controlled by changes in water temperature and/or the oxygen isotope composition of the corresponding lake water $\left(\delta^{18} \mathrm{O}_{\text {lake }}\right)$ which is affected by alterations in lake hydrology and $\delta^{18} \mathrm{O}$ values of atmospheric precipitation $\left(\delta^{18} \mathrm{O}_{\mathrm{p}}\right.$; Leng and Marshall, 2004; Leng and Barker, 2006).

\subsubsection{Water temperature}

During the LGM and late glacial Lake Kotokel summer water temperatures were certainly colder than the modern ones, which yield an average of $18{ }^{\circ} \mathrm{C}$ from May to October (Kostrova et al., 2013a and references therein). Assuming a LGM/late glacial average summer water temperature around $10-12{ }^{\circ} \mathrm{C}$, this would increase $\delta^{18} \mathrm{O}_{\text {diatom }}$ values by $\sim 1.6-1.2 \%$ o due the temperaturedependency of isotope fractionation $\left(-0.2 \% /{ }^{\circ} \mathrm{C}\right.$; Swann and Leng, 2009). Since the mean $\delta^{18} \mathrm{O}_{\text {diatom }}$ value for the LGM/late glacial period is about $1.8 \%$ higher than for the Holocene (Kostrova et al., 2013a), the average offset between the LGM/late glacial and the Holocene oxygen isotope composition could thus be mostly explained by water temperature changes. Diatom assemblages from the LGM and late glacial intervals of the KTK2 core (Fig. 2b; Bezrukova et al., 2010) mainly involve species that usually prevail during the summer period in a wide range of water temperatures, i.e. between $\sim 7-8{ }^{\circ} \mathrm{C}$ and $18-20{ }^{\circ} \mathrm{C}$ (Kuz'mich, 1988; Smol, 1988; Popovskaya et al., 2002; Barinova et al., 2006; Finkelstein and Gajewski, 2008; Rühland et al., 2008; Kuzmin et al., 2009; Wang et al., 2012b). Assuming that water temperature is the primary control for $\delta^{18} \mathrm{O}_{\text {diatom }}$ values from the LGM/late glacial Lake Kotokel record, then the high-frequency variability on the order of $4.5 \%$ would result in a theoretical variation of $22.5^{\circ} \mathrm{C}$ in summer water temperatures. Because the modern water temperature range in Lake Kotokel is only about $14{ }^{\circ} \mathrm{C}$ (Kuz'mich,
1988), a change of $22.5^{\circ} \mathrm{C}$ during the shorter summer period in the colder LGM and late glacial is likely unrealistic. Consequently, water temperature variations can only partly explain the change of $\delta^{18} \mathrm{O}_{\text {diatom }}$ values during the LGM and late glacial. Hence, other factors, i.e. changes in the oxygen isotopic composition of the lake water, need to be considered.

\subsubsection{Hydrology and meteorological background}

The interpretation of diatom isotope records from lake sediments requires an understanding of the modern hydrological conditions and should take possible past changes in the hydrological regime into account.

Recent works (Kostrova et al., 2013a, b) have demonstrated that alterations in the oxygen isotope composition of the Lake Kotokel water throughout the Holocene were mainly caused by (1) changes in $\delta^{18} \mathrm{O}_{\mathrm{p}}$ values in the Kotokel catchment, as well as precipitation amounts and origin; (2) supply of snow melt water to the lake and (3) varying evaporative effects. The following paragraphs aim to discuss the effects of isotope hydrology and local meteorology on the Lake Kotokel $\delta^{18} \mathrm{O}_{\text {diatom }}$ record.

Stable isotope data for precipitation collected in Irkutsk during the time period from 2011 to 2013 show distinct seasonal variations. Summer air masses in the Baikal region display relatively high $\delta{ }^{18} \mathrm{O}_{\mathrm{p}}$ and $\delta \mathrm{D}_{\mathrm{p}}$ values of up to $-4.7 \%$ and $-47.1 \%$, respectively, while winter air masses generally display a lower isotopic composition: in December and January $\delta^{18} \mathrm{O}_{\mathrm{p}}$ and $\delta \mathrm{D}_{\mathrm{p}}$ values may drop to $-39.5 \%$ and $-318.5 \%$, respectively (Table 1 ). The linear correlation between the isotopic composition of precipitation and mean daily air temperatures with precipitation events derived from the global summary of the day data sets provided by the National Oceanic and Atmospheric Administration (NOAA) and the National Climatic Data Center (NCDC; available at: www.ncdc.noaa.gov/ data-access/quick-links) yields: $\delta^{18} \mathrm{O}_{\mathrm{p}}=0.57 \cdot \mathrm{T}_{\mathrm{air}}-19.33 \%$ $\left(R^{2}=0.74\right)$ for oxygen and $\delta \mathrm{D}_{\mathrm{p}}=4.16 \cdot \mathrm{T}_{\mathrm{air}}-149.52 \%\left(R^{2}=0.71\right)$ for hydrogen, reflecting the seasonal changes of precipitation isotope data. Seal and Shanks (1998) calculated a positive relationship of $+0.36 \%$ o $/{ }^{\circ} \mathrm{C}$ for monthly atmospheric air temperature and $\delta^{18} \mathrm{O}_{\mathrm{p}}$ for the Lake Baikal region. Since presently $\mathrm{T}_{\text {air }}$ has a stronger effect on $\delta^{18} \mathrm{O}_{\text {lake }}$ as compared to $\mathrm{T}_{\text {lake }}$ (Kostrova et al., 2013a), we need to consider that $\delta^{18} \mathrm{O}_{\text {diatom }}$ might be related to air temperatures rather than to lake temperatures also during the LGM and late glacial intervals.

Three-year observations show that the isotope composition of the surface Lake Kotokel water has not undergone significant changes and ranges in a relatively narrow span around average values of $-12.2 \%$ for $\delta^{18} \mathrm{O},-107.2 \%$ for $\delta \mathrm{D}$ and is characterized by a low mean $d$ excess of $-9.1 \%$ (Table 1 ). These values indicate a wellmixed lake water environment, which is encompassed by a lack of significant temperature differences between surface and bottom water due to constant wind mixing of the water mass (Kuz'mich, 1988). Lake Kotokel water isotope data plot to the right and below of the GMWL (Fig. 3), following the linear dependence $\delta \mathrm{D}=5.0 \cdot \delta^{18} \mathrm{O}-46.3\left(R^{2}=0.92\right)$, a so called Evaporation Line $(\mathrm{EL})$, indicating that the lake water is influenced by evaporative enrichment. The intersection point of EL and GMWL is at $-18.5 \%$ for $\delta^{18} \mathrm{O}$ and at $-140 \%$ for $\delta \mathrm{D}$ and, hence, quite similar to but a little higher than the mean isotopic composition of the inflow rivers (i.e. around $-20 \%$ in $\delta^{18} \mathrm{O}$, and $-145 \%$ in $\delta \mathrm{D}$, mean $d$ excess around $+13 \%$; Table 1 ), suggesting that Lake Kotokel is predominantly fed by snow melt water from the hinterland and thus by precipitation from higher altitudes characterized by lighter $\delta^{18} \mathrm{O}$ and $\delta$ D values (Kostrova et al., 2013a, b).

As shown above, the River Istok connected to Lake Kotokel (Fig. 1b) can act either as outflow or as inflow depending on whether or not the River Kotochik is filled by melt water. We 
calculated the amount of Lake Kotokel water in the River Kotochik below the confluence of the River Istok using geochemical massbalancing for two-component mixing systems:

$\delta^{18} \mathrm{O}_{\mathrm{KA}}=\mathrm{c}_{\mathrm{KTK}} \cdot \delta^{18} \mathrm{O}_{\mathrm{KTK}}+\mathrm{c}_{\mathrm{KB}} \cdot \delta^{18} \mathrm{O}_{\mathrm{KB}}$,

where $\delta^{18} \mathrm{O}_{\mathrm{KA}}$ is the $\delta^{18} \mathrm{O}$ value for the River Kotochik below the confluence with the River Istok, $\delta^{18} \mathrm{O}_{\mathrm{KTK}}$ is the $\delta^{18} \mathrm{O}$ value for Lake Kotokel at the time of sampling, $\delta^{18} \mathrm{O}_{\mathrm{KB}}$ relates to the River Kotochik above the confluence of the River Istok, $\mathrm{C}_{\mathrm{KTK}}$ is the share of the Lake Kotokel water and $c_{\mathrm{KB}}=\left(1-\mathrm{c}_{\mathrm{KTK}}\right)$ is the share of the River Kotochik water at the confluence of the River Istok.

The $\delta^{18} \mathrm{O}$ and $\delta \mathrm{D}$ values for the River Kotochik above the confluence of the River Istok are $-22.0 \%$ and $-160.7 \%$, respectively. Water from the River Istok at the end of July 2011 shows a relatively constant isotopic composition of $\delta^{18} \mathrm{O}$ around $-20.4 \%$, $\delta \mathrm{D}$ around $-151.0 \%$ and $d$ excess around $+12.3 \%$ (Table 1 ). At the same time, the mean $\delta^{18} \mathrm{O}$ and $\delta \mathrm{D}$ values of the River Kotochik water below the confluence with the River Istok are $-21.6 \%$ and $-157.5 \%$, respectively. This means that, according to our calculation about $6 \%$ of the River Istok water originates from Lake Kotokel, whereas the major part of its water comes from the River Kotochik. This indicates that the water from the River Kotochik might flow into the lake through the Istok. The isotopic data obtained for the Istok-Kotochik river system in 2012 and 2013 (Fig. 1b; Table 1) show a completely different picture. The stable isotope composition of the River Istok water (mean values for $\delta^{18} \mathrm{O}$ around $-12.2 \%$; $\delta \mathrm{D}$ around $-108 \%$ and $d$ excess around $-10.9 \% 0$ ) is similar to that of Lake Kotokel water (Table 1) pointing to Lake Kotokel water as the origin of the River Istok. In accordance with the mixing calculation, about $80 \%$ of the Lake Kotokel water reaches the confluence of the rivers Kotochik and Istok. At a distance of about $2 \mathrm{~km}$ downstream the Kotochik River, the lake water share is reduced to $35 \%$. The results confirm that Kotokel is partly a shallow through-flow lake and partly acts as a closed system while undergoing significant evaporation.

\subsubsection{Species-effect and dissolution}

Additionally, species (or vital) and dissolution effects have to be considered when interpreting diatom isotope data (Leng and Barker, 2006; Mackey et al., 2013). Only one study identified small species effects on marine $\delta^{18} \mathrm{O}_{\text {diatom }}$ (Swann et al., 2008), whereas others found no significant changes of the isotope signal (Moschen et al., 2005; Swann et al., 2006; Chapligin et al., 2012). As this has not been fully investigated in lake environments the possibility cannot be completely excluded. The applied TMSR-cleaning procedure has no potential to separate samples into individual species for isotope analyses and thus to take into account specificspecies changes. The diatom assemblages of the KTK2 core during the LGM and late glacial show some variations. Throughout the interval between $\sim 24.7$ and $21.9 \mathrm{ka} \mathrm{BP}$, S. pinnata agg. valves dominate (up to $82 \%$; Fig. 2b). Biogenic silica from other species in this period is relatively low and, thus, possible effects of changing assemblage composition on $\delta^{18} \mathrm{O}_{\text {diatom }}$ values are also assumed as low. The presence of varying amounts of major species as planktonic A. granulata, E. arenaria var. arenaria and benthic $P$. brevistriata (Fig. 2b; Bezrukova et al., 2010) in the period 17.0-12.7 ka BP may cause some changes in the isotopic signature possibly in consequence of different species-specific fractionation patterns during diatom growth (Chapligin et al., 2012). However, any effect related to blooming in a different season or living in different water depths could be excluded because most Lake Kotokel diatoms predominate in summer time when there are no significant differences in the water isotope composition (Table 1). Additionally, despite a constant trend in the diatom assemblage (from a dominated $P$. brevistriata to $A$. granulata) within this time period no overall trend is visible in the diatom isotope record.

An increase of $\delta^{18} \mathrm{O}_{\text {diatom }}$ values takes place if dissolution of diatoms occurs at pH 9.0 (Moschen et al., 2006). As the modern pH measured at Lake Kotokel varies between 6.8 and 7.3 (Kuz'mich, 1988 ) and the $\mathrm{pH}$ reconstructed on the basis of diatom analysis of the KTK2 core ranges from 4.5 to 8.0 (Bezrukova et al., 2010), it is unlikely that dissolution had an effect on the obtained $\delta^{18} \mathrm{O}_{\text {diatom }}$ values. Additionally, due to the shallowness of Lake Kotokel and the good preservation of Kotokel diatoms under the SEM (Fig. 4), dissolution effects are much less significant than for the deeper Lake Baikal (Ryves et al., 2003; Battarbee et al., 2005). Consequently, it is unlikely that any species-effect or dissolution process changed the isotope signal. Based on the argumentation of the preceding chapters, we believe that the dominant control on $\delta^{18} \mathrm{O}_{\text {diatom }}$ in a colder and drier LGM/late glacial environment, as compared to the Holocene, is evaporation. However, the balance between lake and air temperature changes will certainly affect long-term trends, whereas short-term events to lower $\delta^{18} \mathrm{O}_{\text {diatom }}$ might be related to an increased water supply to the lake, i.e. due to changing precipitation rates or melt water pulses from higher altitudes.
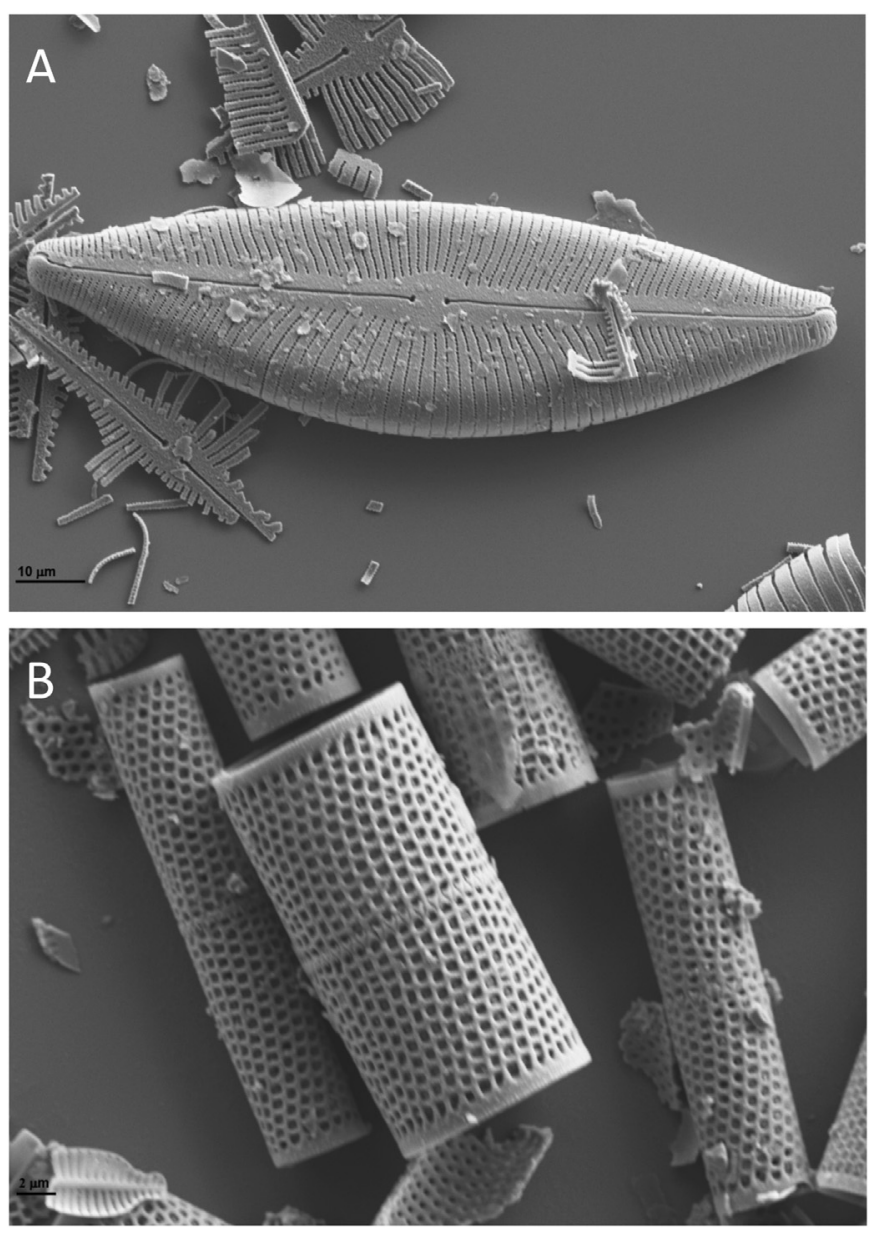

Fig. 4. A and B: SEM pictures of cleaned diatoms from the late glacial part of Lake Kotokel sediments. Traces of dissolution are absent. Fragments of diatoms are the result of mechanical effects during sample preparation. 


\subsection{The LGM and late glacial diatom isotope record and lacustrine environment}

According to palaeoclimate studies based on high-resolution proxy records from Lake Kotokel (Bezrukova et al., 2008, 2010, 2011; Tarasov et al., 2009; Müller et al., 2013) and surrounding peat bogs (Shichi et al., 2009), the LGM/late glacial climate and environment around the lake and its ecosystem underwent significant changes, mainly caused by the long- and short-term variations of temperature and atmospheric precipitation. Pollen-based reconstructions demonstrate a generally colder and drier than present climate over the LGM and late glacial interval (Bezrukova et al., 2010; Müller et al., 2013).

As mentioned above, conditions unfavourable for diatom development occurred between about 31.9 and $24.7 \mathrm{ka}$ BP and 22.0-17.0 ka BP (Fig. 2b and c; Bezrukova et al., 2010) while ostracod shell fragments were discovered in Lake Kotokel within the time interval 26.8-19.1 ka BP (Müller et al., 2013). The diatom isotope record from Lake Kotokel between about 24.7 and (a)

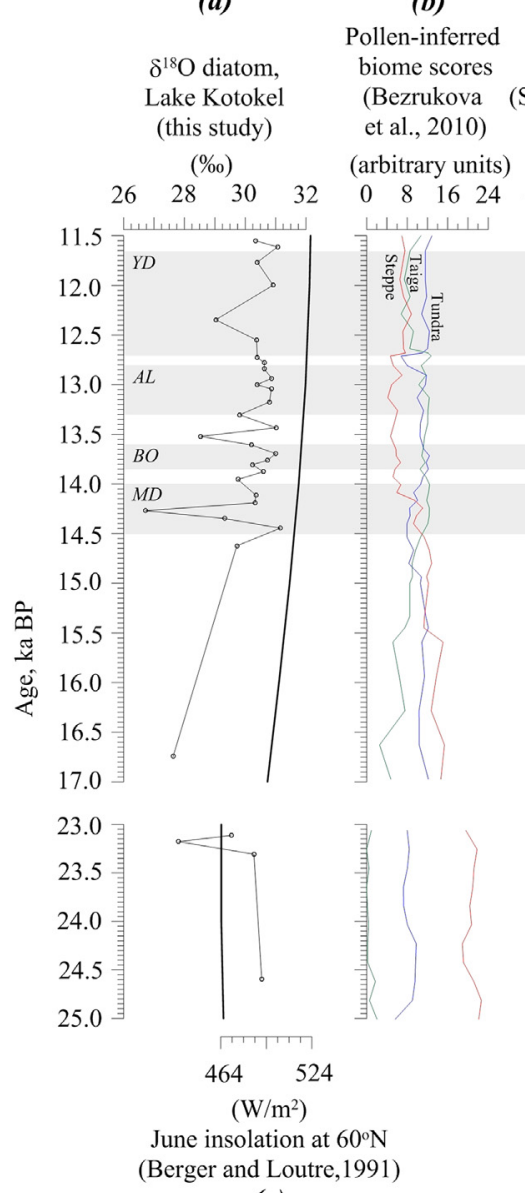

(e) (c)

(d) $\delta^{18} \mathrm{O}$ NGRIP $\quad \delta^{18} \mathrm{O}$ stalagmite ensson et al., D4, China 2008) (Yuan et al., 2004) (\%)

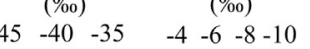
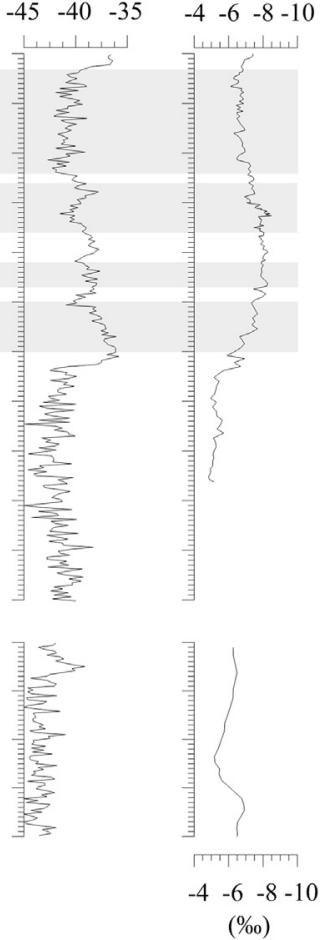

$\delta^{18} \mathrm{O}$ stalagmite MSD, China
(Wang et al., 2001)

Fig. 5. Comparative plots for periods $17-11.5$ and 25-23 ka BP showing (a) corrected $\delta^{18} \mathrm{O}$ isotopic records from Lake Kotokel (this study); (b) the pollen-inferred scores of dominant biomes (Bezrukova et al., 2010) as palaeoclimatic indicators in the Lake Baikal region; along with (c) the NGRIP $\delta^{18} \mathrm{O}$ record from Greenland ice (Svensson et al., 2008) as an indicator of the Northern Hemisphere (NH) air temperature and (d) the $\delta^{18} \mathrm{O}$ records from Chinese stalagmites D4 and MSD (Wang et al., 2001; Yuan et al., 2004) as an indicator of the Pacific monsoon intensity; (e) the NH summer insolation at $60^{\circ} \mathrm{N}$ (Berger and Loutre, 1991). Grey bars indicate the approximate position of the Younger Dryas (YD), Allerød (AL), Bølling (BO) and Meiendorf (MD) identified by pollen and diatom records from Lake Kotokel (Bezrukova et al., 2010).
23.0 ka BP is characterized by a relatively high oxygen isotope composition of $+30.1 \%$ (Fig. 5a) interrupted by an abrupt event of $+28.7 \%$ at $\sim 23.2 \mathrm{ka} \mathrm{BP}$ (Fig. 5a) which is also detected in the NGRIP record (Fig. 5d; Svensson et al., 2008). Over this period, the diatom complex consists of small benthic S. pinnata agg., Staurosira construens agg., $P$. brevistriata and $O$. martyi with a nearly complete dominance of the S. pinnata agg. (Fig. 2b; Bezrukova et al., 2010) suggesting a short open-water season, a turbid environment and a high level of erosion (Smol, 1988). At the same time, the increase in coarse-grained sand particles together with high percentages of Ranunculaceae pollen grains in the Kotokel sediments also points to intensified soil erosion and a much shorter than present distance between the coring site and the shoreline, and thus a reduced lake area (Müller et al., 2013). Taking into account the substantially drier-than-present LGM climate of the Baikal region (Goldberg et al., 2010) and lower-than-present mean July air temperatures of $+13{ }^{\circ} \mathrm{C}$ (Müller et al., 2013), relatively high $\delta^{18} \mathrm{O}_{\text {diatom values in }}$ the interval between $\sim 24.7$ and $23.0 \mathrm{ka}$ BP (Fig. 5a) were most likely caused by enhanced evaporation playing a major role in controlling changes in lake water $\delta^{18} \mathrm{O}$ during this period. Along the north-eastern coast the underwater river channel fills are indicative of a lower lake level prior to $15 \mathrm{ka}$ BP (Zhang et al., 2013), confirming our assumption. At the same time, enhanced evaporation linked to increased aridity in inner Asia (Karabanov et al., 2004; Goldberg et al., 2010) resulted in a lowering of the water level of lakes in Mongolia (Prokopenko et al., 2005) and China (Kramer et al., 2010).

Changes in the lithology and diatom records from Lake Kotokel after 17 ka BP (Fig. 2a and b) indicate the late-glacial climate amelioration in the Baikal region. According to pollen data, the first major warm episode after the LGM occurred at $\sim 14.7 \mathrm{ka}$ BP as indicated by a marked expansion of trees and shrubs and a reduction of steppe vegetation (Fig. 5b; Tarasov et al., 2009; Bezrukova et al., 2010). In the Lake Kotokel sediments diatoms $S$. pinnata and $P$. brevistriata preferring relatively cold water (Finkelstein and Gajewski, 2008) are replaced by comparatively warm-water species $A$. granulata and A. ambigua (Fig. 2b; Popovskaya et al., 2002; Bezrukova et al., 2010). Our $\delta^{18} \mathrm{O}_{\text {diatom }}$ results (Fig. $5 a$ ) point to an increase of about $2 \%$ between 16.7 and $14.4 \mathrm{ka} \mathrm{BP}$, which could be related to the post LGM warming trend. This is in line with an increase in sea surface temperatures in the mid-latitudes of the western North Atlantic to $15-17{ }^{\circ} \mathrm{C}$ at $\sim 15.0$ ka BP (Rodrigues et al., 2010), the strengthening of the East Asian summer monsoon around 14.8 ka BP (Wang et al., 2001, 2012a; Yuan et al., 2004) and an increasing precipitation amount reconstructed in the Baikal region (Demske et al., 2005; Tarasov et al., 2009).

Between 15 and $11.5 \mathrm{ka} \mathrm{BP}$, the isotope composition of Lake Kotokel diatoms (Fig. 5a) remains at a high level reaching $\delta^{18} \mathrm{O}_{\text {diatom }}$ values of up to $+31.2 \%$, interrupted by several single spikes of lower isotope composition (i.e. $+26.7 \%$ at $\sim 14.3 \mathrm{ka} \mathrm{BP} ;+28.5 \%$ at $\sim 13.5 \mathrm{ka} \mathrm{BP} ;+29.0 \%$ at $\sim 12.3 \mathrm{ka} \mathrm{BP})$. The overall high level of $\delta^{18} \mathrm{O}_{\text {diatom }}$ values in a rather cold late glacial interval seems not to correspond to air temperature changes since (1) low $\mathrm{T}_{\text {air }}$ would lead to low $\delta^{18} \mathrm{O}_{\text {lake }}$ and thus low $\delta^{18} \mathrm{O}_{\text {diatom, }}$, (2) several short-term warm and cool phases known from the pollen-based temperature reconstructions (Tarasov et al., 2009; Bezrukova et al., 2010) and NGRIP record (Fig. 5c; Svensson et al., 2008) are not clearly reflected in the $\delta^{18} \mathrm{O}_{\text {diatom }}$ record. The most appropriate way to explain the high $\delta^{18} \mathrm{O}_{\text {diatom }}$ values is a highly evaporative Lake Kotokel system with little precipitation reaching this highly continental site, even in phases of climate amelioration and increasing precipitation amounts (Tarasov et al., 2009; Goldberg et al., 2010). Most likely, while receiving less precipitation, Lake Kotokel acted as a closed-system basin during longer periods per year. 
A general warming corresponding to the MD interstadial observed in the pollen data (Litt and Stebich, 1999; Stebich et al., 2009; Bezrukova et al., 2010; Sirocko, 2012) and in the NGRIP record (Fig. 5c; Svensson et al., 2008) during 14.5-14.0 ka BP might have caused the melting of perennial snowfields or isolated ice caps in the hinterland of Lake Kotokel which could be a source of water with low $\delta^{18} \mathrm{O}$. This melt water input consequently explains the spike around $\sim 14.3 \mathrm{ka} \mathrm{BP}$ in the Lake Kotokel diatom isotope record (Fig. 5a). Shichi et al. (2013) also note a remarkable expansion of river floodplain areas near Lake Baikal and the release of water to the lake basin in response to melting of mountain glaciers and frozen soils under warmer conditions since $\sim 15 \mathrm{ka} B P$. A progressive increase in the abundance of planktonic A. granulata, A. ambigua, $C$. ocellata diatoms in the Lake Kotokel sediments and a noticeable decrease in benthic species (Fig. 2b) indicate a longer open-water season and a deepening of the lake during 14.5-14.0 ka BP (Bezrukova et al., 2010). Around $\sim 14.3 \mathrm{ka}$ BP the total diatom concentration reaches its maximum (Fig. 2c). At the same time, increased amounts of precipitation in north-east China and thawing of local permafrost caused a rise in lake levels (Stebich et al., 2009).

The diatom oxygen isotope record from Lake Kotokel shows a second abrupt event $\left(\delta^{18} \mathrm{O}_{\text {diatom }}=+28.5 \%\right.$ o $)$ registered between $\mathrm{BO}$ and AL interstadials at $\sim 13.5 \mathrm{ka}$ BP (Fig. $5 \mathrm{a}$ ) that could be correlated with the OD cooling (Yu and Eicher, 2001; Stebich et al., 2009). There is some evidence for this event in the KTK2 pollen and diatom records (Bezrukova et al., 2010) and a relatively low value of $+24.9 \%$ was also detected in the $\delta^{18} \mathrm{O}$ diatom record from Lake Baikal (Mackay et al., 2011) at 13.4 ka BP. These declines in both records are in line with a short-term negative oxygen isotope shift in the NGRIP ice core (Fig. 5c; Svensson et al., 2008). A climatic deterioration around 13.6-13.4 ka BP has been clearly documented in several high-resolution records from Europe, North America and Asia (Yu and Eicher, 2001; Lauterbach et al., 2011; Zhao et al., 2013), related to a shift in atmospheric circulation patterns and instantaneous environmental responses to this change. At this time, the replacement of spruce and fir forests by shrubby alder and dwarf birch associations around Lake Kotokel suggests cooler and moderately wet conditions with $300-320 \mathrm{~mm} / \mathrm{y}$ precipitation likely prevailed in winter (Tarasov et al., 2009; Bezrukova et al., 2011). The alder community commonly grows within wet, but swamp-devoid areas in winter covered by a thick snow layer (Gerasimov, 1966).

At 13.5-12.8 ka BP the Baikal region climate became warm and wet according to pollen-based quantitative reconstructions (Tarasov et al., 2007, 2009). In Lake Kotokel the sedimentation type changed from mainly minerogenic to organogenic (Bezrukova et al., 2008). The almost complete dominance of planktonic $A$. granulata and $A$. ambigua diatom species and benthic Staurosira construens agg. in the sediments (Fig. 2b) indicates the deepening of the lake (Bezrukova et al., 2010). However, the $\delta^{18} \mathrm{O}_{\text {diatom values are at a high }}$ level around $+30.5 \%$ until $~ 12.8-12.7 \mathrm{ka}$ BP showing no significant response to the mentioned environmental changes. At that time the amount of precipitation reached $\sim 400 \mathrm{~mm}$, comparable to present levels (Tarasov et al., 2009), and the stalagmite oxygen isotope record from China demonstrates a strengthening of the East Asian summer monsoon between 13.5 and 13 ka BP (Fig. 5d; Yuan et al., 2004; Wang et al., 2012a).

The YD stadial had global effects on the environment including the Baikal region where it has been clearly identified between $\sim 12.7$ and 11.65 ka BP (Bezrukova et al., 2010). A decrease in mass accumulation rates of total organic carbon and in concentrations of biogenic silica and diatoms took place in Lake Baikal (Mackay, 2007; Mackay et al., 2011 and references therein). Around Lake Kotokel a reduction of forest vegetation and an expansion of steppe and tundra associations occurred (Fig. 5b; Bezrukova et al., 2010). Pollen-based reconstructions suggest lower than present temperatures (by $2-4 \mathrm{C}^{\circ}$ in July and by $8 \mathrm{C}^{\circ}$ in January) and lower precipitation (by $100 \mathrm{~mm} / \mathrm{yr}$ ) in the region for this period (Tarasov et al., 2007, 2009). However, the Lake Kotokel $\delta^{18} \mathrm{O}_{\text {diatom }}$ record (Fig. 5a) only shows a minor decline of about $1.3 \%$ 12.8-12.4 ka BP, which is accompanied by the appearance of coldwater E. arenaria var. arenaria (Fig. $2 b$ ) and in line with lower air temperatures in the region during the YD (Tarasov et al., 2009). The oxygen isotope record from Lake Baikal demonstrates a similar distribution of $\delta^{18} \mathrm{O}_{\text {diatom values between }} \sim 2.8$ and $11.6 \mathrm{ka} \mathrm{BP}$ (Mackay et al., 2011). The YD $\delta^{18} \mathrm{O}_{\text {diatom }}$ spike is also roughly synchronous with the oxygen isotope records from Greenland (Fig. 5c; Svensson et al., 2008) and from China (Fig. 5d; Yuan et al., 2004). However, neither a preceding warm AL nor a cold YD are readily visible in the Lake Kotokel $\delta^{18} \mathrm{O}_{\text {diatom }}$ record.

The overall trend of the Lake Kotokel isotope record spanning the period between $\sim 15.0$ and $11.5 \mathrm{ka} \mathrm{BP}$ (Fig. $5 \mathrm{a}$ ) is similar to that of June insolation at $60^{\circ}$ (Fig. 5e; Berger and Loutre, 1991) suggesting that the diatom $\delta^{18} \mathrm{O}$ value is a sensitive parameter responding to changes in solar activity. Despite a visible reaction of the late glacial oxygen isotope record from Lake Kotokel to regional changes in air temperatures as single spikes, the effect of $T_{\text {air }}$ on $\delta^{18} \mathrm{O}$ of the lake water was smaller in comparison to evaporation. The mean $\delta^{18} \mathrm{O}_{\text {diatom }}$ value for the LGM/last glacial periods has been determined as $+30.1 \%$ which is about $1.8 \%$ higher than for the Holocene (Kostrova et al., 2013a) suggesting that during the LGM and late glacial, Lake Kotokel was a strongly evaporative system. This is in line with a strengthening of the Siberian High likely causing increased aridity in the catchment of Lake Kotokel and altering fluvial input into the lake. Apparently, LGM/late glacial winters were characterized by less snow than present, which could have lead to a reduction of river input from higher altitudes and hence an isotope enrichment of the lake water.

\section{Conclusions}

This paper presents the newly obtained oxygen isotope record on fossil diatoms retrieved from a sediment core from Lake Kotokel and used for reconstructing climate and environment dynamics in the Baikal region during the LGM and late glacial times. The present study has shown the possibility of applying the TMSR as an alternative technique for extracting and cleaning diatoms for oxygen isotope analysis.

Our study provides important information on environment and climate history of the Baikal region in central Asia during the LGM and the late glacial intervals indicating that the temperature and moisture variations influenced the oxygen isotope values in fossil diatoms from Lake Kotokel. The broad similarities between the Lake Kotokel diatom isotope record and Northern Hemisphere solar insolation show that $\delta^{18} \mathrm{O}_{\text {diatom }}$ responded well to the insolationinduced temperature changes. The combination of the $\delta^{18} \mathrm{O}_{\text {diatom }}$ record with pollen and diatom data allows discussion of regional environmental changes and their responses in the lake ecosystem in more detail. We suggest that Lake Kotokel acted for most of the late glacial as a strongly evaporative system. Enhanced evaporation and prevalent summer precipitation in the region are the main reasons for overall high $\delta^{18} \mathrm{O}_{\text {diatom values up to }+31.2 \% \text { during a dry }}$ and cold LGM/late glacial. Enhanced melt water input from the hinterland (i.e. at $\sim 14.3 \mathrm{ka} \mathrm{BP}$ ) as a reaction to warming pulses was detected as minima in the $\delta^{18} \mathrm{O}$ record of Lake Kotokel. This study demonstrates the complex interplay of global and regional-scale hydrological and climatological factors controlling the $\delta^{18} \mathrm{O}_{\text {diatom }}$ especially in a cold glacial environment substantially different from present day conditions. 


\section{Acknowledgements}

This study is a contribution to the research program "Bridging Eurasia" supported by German Research Foundation (DFG; grants TA-540/4, TA 540/5) and the Russian Foundation for Basic Research (RFBR; grant 12-05-00476a). The study was also partly supported by the DFG grants Me-3266-3-1, Me-3266-5-1 and by the German Academic Exchange Service (DAAD; grant A-13-00095). The authors would like to thank Helga Kemnitz from GFZ for her SEM support. Additional thanks are owed to Gennady Kalmychkov and Valery Bychincky from VIG SB RAS for their active participation in the sampling of Lake Kotokel water and for discussions about the influence of TMSR on oxygen isotope data. Special thanks are also due to Lutz Schönicke (AWI), Yury Suslikov and Pavel Borovets (Arnika Industrial Service) for their technical support and to Giles Shephard for polishing English. We sincerely thank three anonymous reviewers for valuable and constructive comments and suggestions that helped improve an earlier version of this manuscript.

\section{References}

Barinova, S.S., Medvedeva, L.A., Anisimova, O.V., 2006. Diversity of Algal Indicators in the Environmental Assessment. Pilies Studio, Tel Aviv, p. 498.

Battarbee, R.W., Mackay, A.W., Jewson, D.H., Ryves, D.B., Sturm, M., 2005. Differential dissolution of Lake Baikal diatoms: correction factors and implications for palaeoclimatic reconstruction. Global and Planetary Change 46, 75-86.

Berger, A., Loutre, M.F., 1991. Insolation values for the climate of the last 10 million years. Quaternary Science Reviews 10 (4), 297-317.

Bezrukova, E.V., Krivonogov, S.K., Takahara, H., Letunova, P.P., Shichi, K. Abzaeva, A.A., Kulagina, N.V., Zabelina, Yu, S., 2008. Lake Kotokel as a stratotype for the Late Glacial and Holocene in Southeastern Siberia. Doklady Earth Sciences 420 (4), 658-663.

Bezrukova, E.V., Tarasov, P.E., Solovieva, N., Krivonogov, S.K., Riedel, F., 2010. Last glacial-interglacial vegetation and environmental dynamics in southern Siberia: chronology, forcing and feedbacks. Palaeogeography, Palaeoclimatology, Palaeoecology 296, 185-198.

Bezrukova, E.V., Tarasov, P.E., Kulagina, N.V., Abzaeva, A.A., Letunova, P.P., Kostrova, S.S., 2011. Palynological study of Lake Kotokel' bottom sediments. Russian Geology and Geophysics 52, 457-464.

Boës, X., Piotrowska, N., Fagel, N., 2005. High-resolution diatom/clay record in Lake Baikal from grey scale, and magnetic susceptibility over Holocene and Termination I. Global and Planetary Change 46, 299-313.

Brandriss, M.E., O'Neil, J.R., Edlund, M.B., Stoermer, E.F., 1998. Oxygen isotope fractionation between diatomaceous silica and water. Geochimica et Cosmochimica Acta 62, 1119-1125.

Brewer, T.S., Leng, M.J., Mackay, A.W., Lamb, A.L., Tyler, J.J., Marsh, N.G., 2008 Unravelling contamination signals in biogenic silica oxygen isotope composition: the role of major and trace element geochemistry. Journal of Quaternary Science 23 (4), 321-330.

Chapligin, B., Meyer, H., Friedrichsen, H., Marent, A., Sohns, E., Hubberten, H.-W. 2010. A high-performance, safer and semi-automated approach for the $\delta^{18} \mathrm{O}$ analysis of diatom silica and new methods for removing exchangeable oxygen. Rapid Communications in Mass Spectrometry 24, 2655-2664.

Chapligin, B., Leng, M.J., Webb, E., Alexandre, A., Dodd, J.P., Ijiri, A., Lücke, A., Shemesh, A., Abelmann, A., Herzschuh, H., Longstaffe, F.J., Meyer, $H$, Moschen, R., Okazaki, Y., Rees, N.H., Sharp, Z.D., Sloane, H.J., Sonzongi, C. Swann, J.E.A., Sylvestre, F., Tyler, J.J., Yam, R., 2011. Inter-laboratory comparison of oxygen isotope compositions from biogenic silica. Geochimica et Cosmochimica Acta 75, 7242-7256.

Chapligin, B., Meyer, H., Bryan, A., Snyder, J., Kemnitz, H., 2012. Assessment of purification and contamination correction methods for analysing the oxygen isotope composition from biogenic silica. Chemical Geology 300-301, 185-199.

Clayton, R., Mayeda, T., 1963. The use of bromine pentafluoride in the extraction of oxygen from oxides and silicates for isotopic analysis. Geochimica et Cosmochimica Acta 27, 43-52.

Cook, C.C., Leng, M.J., Jones, R.T., Langdon, P.G., Zhang, E., 2012. Lake ecosystem dynamics and links to climate change inferred from a stable isotope and organic palaeorecord from a mountain lake in southwestern China (ca. 22.6-10.5 cal ka BP). Quaternary Research 77, 132-137.

Craig, H., 1961. Isotopic variations in meteoric waters. Science 133, 1702-1703.

Demske, D., Heumann, G., Granoszewski, W., Nita, M., Mamakowa, K., Tarasov, P.E. Oberhansli, H., 2005. Late glacial and Holocene vegetation and regional climate variability evidenced in high-resolution pollen records from Lake Baikal. Global and Planetary Change 46, 255-279.

Diefendorf, A.F., Patterson, W.P., Mullins, H.T., Tibert, N., Martini, A., 2006. Evidence for high-frequency late Glacial to mid-Holocene $(16,800$ to $5000 \mathrm{cal}$ yr B.P.) climate variability from oxygen isotope values of Lough Inchiquin, Ireland. Quaternary Research 65, 78-86.
Finkelstein, S.A., Gajewski, K., 2008. Responses of Fragilarioid-dominated diatom assemblages in a small Arctic lake to Holocene climatic changes, Russell Island, Nunavut. Canada. Journal of Paleolimnology 40, 1079-1095.

Florensov, N.A., 1960. Mezozoiskie i kainozoiskie vpadini Pribaikal'ya. Izdatel'stvo Akademii Nauk SSSR, Moscow-Leningrad, p. 258 (in Russian).

Galaziy, G.I. (Ed.), 1993. Baikal Atlas. Federal Agency for Geodesy and Cartography of Russia, Moscow (in Russian).

Gerasimov, I.P. (Ed.), 1966. Natural Conditions and Natural Resources of the USSR: North of the European Part of the USSR. Nauka, Moscow, p. 452 (in Russian)

Goldberg, E.L., Chebykin, E.P., Zhuchenko, N.A., Vorobyeva, S.S., Stepanova, O.G., Khlystov, O.M., Ivanov, E.V., Weinberg, E., Gvozdkov, A.N., 2010. Uranium isotopes as proxies of the environmental history of the Lake Baikal watershed (East Siberia) during the past 150 ka. Palaeogeography, Palaeoclimatology, Palaeoecology 294, 16-29.

Hernandez, A., Bao, R., Giralt, S., Barker, P.A., Leng, M.J., Sloane, H.J., Sáez, A., 2011. Biogeochemical processes controlling oxygen and carbon isotopes of diatom silica in Late Glacial to Holocene lacustrine rhythmites. Palaeogeography, Palaeoclimatology, Palaeoecology 299, 413-425.

Hernandez, A., Bao, R., Giralt, S., Sáez, A., Leng, M.J., Barker, P.A., Kendrick, C.P., Sloane, H.J., 2013. Climate, catchment runoff and limnological drivers of carbon and oxygen isotope composition of diatom frustules from the central Andean Altiplano during the Lateglacial and Early Holocene. Quaternary Science Reviews 66, 64-73.

Iler, R.K., 1979. The Chemistry of Silica: Solubility, Polymerization, Colloid and Surface Properties and Biochemistry of Silica. Wiley-Interscience Publication, New-York, Chichester, Bribano, Toronto, p. 866.

Karabanov, E., Williams, D., Kuzmin, M., Sideleva, V., Khursevich, G., Prokopenko, A., Solotchina, E., Tkachenko, L., Fedenya, S., Kerber, E., 2004. Ecological collapse of Lake Baikal and Lake Hovsgol ecosystems during the Last Glacial and consequences for aquatic species diversity. Palaeogeography, Palaeoclimatology, Palaeoecology 209, 227-243.

Kashutina, M.V., Ioffe, S.L., Tartakovskii, V.A., 1975. Silylation of organic compounds. Russian Chemical Reviews 44 (9), 733-747.

Kalmychkov, G.V. Kostrova, S.S., Geletii, V.F, Tkachenko, L.L., Rakhlin, V.I. 2005. Method of separation of diatom frustules from bottom sediments for oxygen isotopic analysis and paleoclimatic reconstruction. Geochemistry International 43, 1252-1254.

Kalmychkov, G.V., Kuz'min, M.I., Pokrovskii, B.G., Kostrova, S.S., 2007. Oxygen isotopic composition in diatom algae frustules from Lake Baikal sediments: annual mean temperature variations during the last 40 Ka. Doklady Earth Sciences 413 (2), 206-209.

Kostrova, S.S., Meyer, H., Chapligin, B., Kossler, A., Bezrukova, E.V., Tarasov, P.E., 2013a. Holocene oxygen isotope record of diatoms from Lake Kotokel (southern Siberia, Russia) and its palaeoclimatic implications. Quaternary International 290-291, 21-34.

Kostrova, S.S., Meyer, H., Chapligin, B., Bezrukova, E.V., Tarasov, P.E., Kuz'min, M.I., 2013b. Reconstruction of the Holocene climate of Transbaikalia: evidence from the oxygen isotope analysis of fossil diatoms from Lake Kotokel. Doklady Earth Sciences 451 (1), 732-736.

Kramer, A., Herzschuh, U., Mischke, S., Zhang, C., 2010. Late glacial vegetation and climate oscillations on the southeastern Tibetan Plateau inferred from the Lake Naleng pollen profile. Quaternary Research 73, 324-335.

Kurita, N., Yoshida, N., Inoue, G., Chayanova, E.A., 2004. Modern isotope climatology of Russia: a first assessment. Journal of Geophysical Research 109 (D03102), $1-15$.

Kuz'mich, V.N. (Ed.), 1988. Bioproduktivnost‘ evtrophnich ozer Irkana i Kotokel basseina ozera Baikal. Sbornik Nauchnih Trudov GosNIOPH, vol. 279, p. 150 (in Russian).

Kuzmin, M.I., Khursevich, G.K., Prokopenko, A.A., Fedenya, S.A., Karabanov, E.B., 2009. Centric Diatoms in Lake Baikal during the Late Cenozoic: Morphology, Systematics, Stratigraphy and Stages of Development (Based on the Deep Cores of the Baikal Drilling Project). Academic Publishing House "GEO", Novosibirsk, p. 374 (in Russian).

Laufer, S., Roy, W., 1972. German Federal Republic Patent 2043629 (Degussa).

Lauterbach, S., Brauer, A., Andersen, N., Danielopol, D.L., Dulski, P., Hüls, M. Milecka, K., Namiotko, T., Obremska, M., Von Grafenstein, U., Participants, D., 2011. Environmental responses to Lateglacial climatic fluctuations recorded in the sediments of pre-Alpine Lake Mondsee (northeastern Alps). Journal of Quaternary Science 26 (3), 253-267.

Last, W.M., Smol, J.P. (Eds.), 2001. Tracking Environmental Change Using Lake Sediments. Basin analysis, Coring and Chronological Techniques, vol. 1. Kluwer Academic Publishers, p. 576.

Leng, M.J., Marshall, J.D., 2004. Palaeoclimate interpretation of stable isotope data from lake sediment archives. Quaternary Science Reviews 23, 811-831.

Leng, M.J., Barker, P.A., 2006. A review of the oxygen isotope composition of lacustrine diatom silica for palaeoclimate reconstruction. Earth-Science Reviews 75, 5-27.

Leng, M.J., Wagner, B., Boehm, A., Panagiotopoulos, K., Vane, C.H., Snelling, F., Haidon, C., Woodley, E., Vogel, H., Zanchetta, G., Baneschi, I., 2013. Understanding past climatic and hydrological variability in the Mediterranean from Lake Prespa sediment isotope and geochemical record over the Last Glacial cycle. Quaternary Science Reviews 66, 123-136.

Li, L., Mackay, A.W., Zhang, Y., Li, J., 2013. A 1000-year record of vegetation change and wildfire from maar lake Erlongwan in northeast China. Quaternary International 290-291, 313-321. 
Litt, T., Stebich, M., 1999. Bio- and chronostratigraphy of the lateglacial in the Eifel region, Germany. Quaternary International 61, 5-16.

Lydolph, P.E., 1977. Climates of the Soviet Union. In: World Survey of Climatology, vol. 7. Elsevier Scientific Publishing Company, Amsterdam-Oxford-New York, p. 443.

Mackay, A.W., 2007. The paleoclimatology of Lake Baikal: a diatom synthesis and prospectus. Earth-Science Reviews 82, 181-215.

Mackay, A.W., Swann, G.E.A., Brewer, T.S., Leng, M.J., Morley, D.W., Piotrowska, N., Rioual, P. White, D., 2011. A reassessment of late glacial - Holocene diatom oxygen isotope record from Lake Baikal using a geochemical mass-balance approach. Journal of Quaternary Science 26 (6), 627-634.

Mackay, A.W., Swann, G.E.A., Fagel, N., Fietz, S., Leng, M.J., Morley, D., Rioual, P., Tarasov, P., 2013. Hydrological instability during the Last Interglacial in central Asia: a new diatom oxygen isotope record from Lake Baikal. Quaternary Science Reviews 66, 45-54.

Meyer, H., Schönicke, L., Wand, U., Hubberten, H.-W., Friedrichsen, H., 2000. Isotope studies of hydrogen and oxygen in ground ice - experiences with the equilibration technique. Isotopes in Environmental and Health Studies 36, 133-149.

Morley, D.W., Leng, M.J., Mackay, A.W., Sloane, H.J., 2005. Late glacial and Holocene environmental change in the Lake Baikal region documented by oxygen isotopes from diatom silica. Global and Planetary Change 46, 221-233.

Morley, D.W., Leng, M.J., Mackay, A.W., Sloane, H.J., Rioual, P., Battarbee, R.W., 2004. Cleaning of lake sediment samples for diatom oxygen isotope analysis. Journal of Paleolimnology 31, 391-401.

Moschen, R., Lücke, A., Schleser, G.H., 2005. Sensitivity of biogenic silica oxygen isotopes to changes in surface water temperature and palaeoclimatology. Geophysical Research Letters 32, L07708. http://dx.doi.org/10.1029/ 2004GL022167.

Moschen, R., Lücke, A., Parplies, J., Radtke, U., Schleser, G.H., 2006. Transfer and early diagenesis of biogenic silica oxygen isotope signals during settling and sedimentation of diatoms in a temperate freshwater lake (Lake Holzmaar, Germany). Geochimica et Cosmochimica Acta 70, 4367-4379.

Müller, S., Tarasov, P.E., Andreev, A.A., Tütken, T., Gartz, S., Diekmann, B., 2010. Late Quaternary vegetation and environments in the Verkhoyansk Mountains region (NE Asia) reconstructed from a 50-ka fossil pollen record from Lake Billyakh. Quaternary Science Reviews 29, 2071-2086.

Müller, S., Tarasov, P.E., Hoelzmann, P., Bezrukova, E.V., Kossler, A., Krivonogov, S.K., 2013. Stable vegetation and environmental conditions during the Last Glacial Maximum: New results from Lake Kotokel (Lake Baikal region, southern Siberia, Russia). Quaternary International. http://dx.doi.org/10.1016/j.quaint. 2013.12.012.

Nakagawa, T., Kitagawa, H., Yasuda, Y., Tarasov, P.E., Gotanda, K., Sawai, Y., 2005. Pollen/event stratigraphy of the varved sediment of Lake Suigetsu, central Japan from 15,701 to 10,217 SG vyr BP (Suigetsu varve years before present): description, interpretation, and correlation with other regions. Quaternary Science Reviews 24 (14-15), 1691-1701.

Peck, J.A., Khosbayar, P., Fowell, S.J., Pearce, R.B., Ariunbileg, S., Hansen, B.C.S., Soninkhishig, N., 2002. Mid to Late Holocene climate change in north central Mongolia as recorded in the sediments of Lake Telmen. Palaeogeography, Palaeoclimatology, Palaeoecology 183, 135-153.

Popovskaya, G.I., Genkal, S.I., Likhoshway, YeV., 2002. Diatoms of the Plankton of Lake Baikal: Atlas and Key. Nauka, Novosibirsk, p. 168 (in Russian).

Prokopenko, A.A., Williams, D.F., Karabanov, E.B., Khursevich, G.K., 2001. Continental response to Heinrich events and Bond cycles in sedimentary record of Lake Baikal, Siberia. Global and Planetary Change 28, 217-226.

Prokopenko, A.A., Williams, D.F., 2004. Deglacial methane emission signals in the carbon isotopic record of Lake Baikal. Earth and Planetary Science Letters 218, 135-147.

Prokopenko, A.A., Kuzmin, M.I., Williams, D.F., Gelety, V.F., Kalmychkov, G.V., Gvozdkov, A.N., Solotchin, P.A., 2005. Basin-wide sedimentation changes and deglacial lake-level rise in the Hovsgol basin, NW Mongolia. Quaternary International 136, 59-69.

Ryves, D.V., Jewson, D.H., Sturm, M., Battarbee, R.W., Flower, R.J., Mackay, A.W., Granin, N.G., 2003. Quantitative and qualitative relationships between planktonic diatom communities and diatom assemblages in sedimenting material and surface sediments in Lake Baikal, Siberia. Limnology and Oceanography 48 1643-1661.

Rodrigues, T., Grimalt, J.O., Abrantes, F., Naughton, F., Flores, J., 2010. The last glacial-interglacial transition (LGIT) in the western mid-latitudes of the North Atlantic: abrupt sea surface temperature change and sea level implications. Quaternary Science Reviews 29, 1853-1862.

Rozanski, K., Araguás-Araguás, L., Gonfiantini, R., 1993. Isotopic patterns in modern global precipitation. Geophysical Monograph. In: Climate Change in Continental Isotope Records, vol. 78. American Geophysical Union, pp. 1-36.
Rühland, K.M., Paterson, A.M., Smol, J.P., Pienitz, R., 2008. Hemispheric-scale patterns of climate-related shifts in planktonic diatoms from North American and European lakes. Global Change Biology 14, 2740-2754.

Seal, R.R., Shanks, W.C., 1998. Oxygen and hydrogen isotope systematics of Lake Baikal, Siberia: implications for paleoclimate studies. Limnology and Oceanography $43,1251-1261$.

Shichi, K., Takahara, H., Krivonogov, S.K., Bezrukova, E.V., Kashiwaya, K., Takehara, A., Nakamura, T., 2009. Late Pleistocene and Holocene vegetation and climate records from Lake Kotokel, central Baikal region. Quaternary International 205 (1-2), 98-110.

Shichi, K., Takahara, H., Hase, Y., Watanabe, T., Nara, F.W., Nakamura, T., Tani, Y. Kawai, T., 2013. Vegetation response in the southern Lake Baikal region to abrupt climate events over the past 33 cal kyr. Palaeogeography, Palaeoclimatology, Palaeoecology 375, 70-82.

Sirocko, F. (Ed.), 2012. Wetter, Klima, Menschheitsentwicklung von der Eiszeit bis ins 21. Jahrhundert. Konrad Theiss Verlag, Darmstadt, p. 208.

Sklyarov, E.V., Solotchina, E.P., Vologina, E.G., Ignatova, N.V., Izokh, O.P. Kulagina, N.V., Sklyarova, O.A., Solotchin, P.A., Stolpovskaya, V.N., Ukhova, N.N. Fedorovskii, V.S., Khlystov, O.M., 2010. Detailed Holocene climate record from the carbonate section of saline Lake Tsagan-Tyrm (West Baikal area). Russian Geology and Geophysics 51, 237-258.

Smol, J.P., 1988. Palaeoclimate proxy data from freshwater diatoms. Verhandlungen des Internationalen Verein Limnologie 23, 837-844.

Stebich, M., Mingram, J., Han, J., Liu, J., 2009. Late Pleistocene spread of (cool-) temperate forests in Northeast China and climate changes synchronous with the North Atlantic region. Global and Planetary Change 65, 56-70.

Subetto, D.A., 2009. Donnie otlozheniya ozer: paleolimnologicheskie reconstruktsii. Izdatel‘tsvo RGPY im. A.I. Gertsena, Moscow, p. 339 (in Russian).

Svensson, A., Andersen, K.K., Bigler, M., Clausen, H.B., Dahl-Jensen, D., Davies, S.M., Johnsen, S.J., Muscheler, R., Parrenin, F., Rasmussen, S.O., Röthlisberger, R. Seierstad, I., Steffensen, J.P., Vinther, B.M., 2008. A 60000 year Greenland stratigraphic ice core chronology. Climate of the Past 4, 47-57.

Swann, G.E.A., Maslin, M.A., Leng, M.J., Sloane, H.J., Haug, G.H., 2006. Diatom $\delta^{18} \mathrm{O}$ evidence for the development of the modern halocline system in the subarctic north-west Pacific at the onset of major Northern Hemisphere glaciation. Paleoceanography 21, PA1009. http://dx.doi.org/10.1029/2005PA001147.

Swann, G.E.A., Leng, M.J., Sloane, H.J., Maslin, M.A., 2008. Isotope offsets in marine diatom $\delta^{18} \mathrm{O}$ over the last $200 \mathrm{ka}$. Journal of Quaternary Science 23, 389-400.

Swann, G.E.A., Leng, M.J., 2009. A review of diatom $\delta^{18} \mathrm{O}$ in palaeoceanography. Quaternary Science Reviews 28, 384-398.

Swann, G.E.A., Leng, M.J., Juschus, O., Melles, M., Brigham-Grette, J., Sloane, H.J. 2010. A combined oxygen and silicon diatom isotope record of Late Quaternary change in Lake El'gygytgyn, North East Siberia. Quaternary Science Reviews 29 $774-786$.

Tarasov, P., Bezrukova, E., Karabanov, E., Nakagava, T., Wagner, M., Kulagina, N. Letunova, P., Abzaeva, A., Granoszewski, W., Riedel, F., 2007. Vegetation and climate dynamics during the Holocene and Eemian interglacials derived from Lake Baikal pollen records. Palaeogeography, Palaeoclimatology, Palaeoecology 252, 440-457.

Tarasov, P.E., Bezrukova, E.V., Krivonogov, S.K., 2009. Late Glacial and Holocene changes in vegetation cover and climate in southern Siberia derived from a 15 kyr long pollen record from Lake Kotokel. Climate of the Past 5, 285-295.

Wang, Y.J., Cheng, H., Edwards, R.L., An, Z.S., Wu, J.Y., Shen, C.-C., Dorale, J.A., 2001 A high-resolution absolute-dated Late Pleistocene Monsoon record from Hulu Cave, China. Science 294, 2345-2348.

Wang, L., Li, J., Lu, H., Gu, Z., Rioual, P., Hao, Q., Mackay, A.W., Jiang, W., Cai, B., Xu, B. Han, J., Chu, G., 2012a. The East Asian winter monsoon over the last 15,500 years: its links to high-latitudes and tropical climate systems and complex correlation to the summer monsoon. Quaternary Science Reviews 32, 131-142.

Wang, Q., Yang, X., Hamilton, P.B., Zhang, E., 2012b. Linking spatial distributions of sediment diatom assemblages with hydrological depth profiles in a plateau deep-water lake system of subtropical China. Fottea 12 (1), 59-73.

Yu, Z., Eicher, U., 2001. Three amphi-Atlantic century-scale cold events during the Bølling - Allerød warm period. Geographie physique et Quaternaire 55 (2) $171-179$.

Yuan, D.X., Cheng, H., Edwards, R.L., Dykoski, C.A., Kelly, M.J., Zhang, M.L., Qing, J.M. Lin, Y.S., Wang, Y.J., Wu, J.Y., Dorale, J.A., An, Z.S., Cai, Y.J., 2004. Timing, duration, and transitions of the Last Interglacial Asian monsoon. Science 304, 575-578.

Zhang, Y. Wünnemann, B., Bezrukova, E.V., Ivanov, E.V., Shchetnikov, A.A. Nourgaliev, D., Levina, O.V., 2013. Basin morphology and seismic stratigraphy of Lake Kotokel, Baikal region, Russia. Quaternary International 290-291, 57-67.

Zhao, K., Li, X., Dodson, J., Zhou, X., Atahan, P., 2013. Climate instability during the last deglaciation in central Asia, reconstructed by pollen data from Yili Valley, NW China. Review of Palaeobotany and Palynology 189, 8-17. 